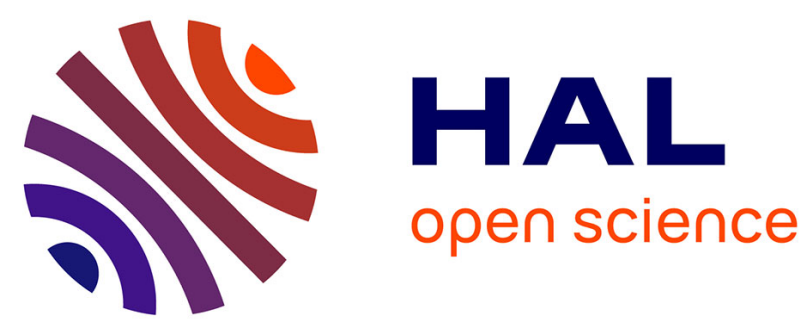

\title{
Pleistocene Carnivora (Mammalia) from Tighennif (Ternifine), Algeria
}

Denis Geraads

\section{To cite this version:}

Denis Geraads. Pleistocene Carnivora (Mammalia) from Tighennif (Ternifine), Algeria. Geobios, 2016, 94 (3), 10.1016/j.geobios.2016.09.001 . hal-01393484

\section{HAL Id: hal-01393484 https://hal.sorbonne-universite.fr/hal-01393484}

Submitted on 7 Nov 2016

HAL is a multi-disciplinary open access archive for the deposit and dissemination of scientific research documents, whether they are published or not. The documents may come from teaching and research institutions in France or abroad, or from public or private research centers.
L'archive ouverte pluridisciplinaire HAL, est destinée au dépôt et à la diffusion de documents scientifiques de niveau recherche, publiés ou non, émanant des établissements d'enseignement et de recherche français ou étrangers, des laboratoires publics ou privés. 


\title{
Pleistocene Carnivora (Mammalia) from Tighennif (Ternifine), Algeria *
}

Denis Geraads *

Centre de Recherche sur la Paléobiodiversité et les Paléoenvironnements (UMR 7207), Sorbonne Universités, MNHN, CNRS, UPMC, CP 38, 8 rue Buffon, 75231 PARIS Cedex 05, France

*E-mail address: geraads@mnhn.fr.

${ }^{\star}$ Corresponding editor: Gildas Merceron.

\begin{abstract}
The site of Tighennif (= Ternifine) in Northern Algeria, well-known for its Homo mauritanicus (= Homo rhodesiensis?) remains, and probably dating to the late Calabrian, yielded a large assemblage of terrestrial carnivores. Some are identical or probably identical with extant species: Crocuta crocuta and Hyaena hyaena (Hyaenidae), Felis silvestris (Felidae), Mellivora capensis and Poecilictis cf. libyca (Mustelidae), and Vulpes cf. rueppelli (Canidae). In addition, among felids there is an unidentified leopard-like form; a smaller, more common species assigned to Lynx sp. (a genus quite rare in Africa) but which is certainly different from modern forms, an Homotherium that seems to be the last occurrence of the machairodonts in Africa, and a Panthera aff. leo, which is unfortunately too poorly known to be named. Rare bears do not display all derived features of later North African $U$. bibersoni. Among canids, the Nyctereutes-like jackal Lupulella mohibi is an endemic North African form known until the late middle Pleistocene, and the hunting dog Lycaon magnus is also clearly distinct from the modern species. A single new species is described, Enhydrictis hoffstetteri, a large, otter-like member of the Mustelidae, of a genus that was previously unknown from Africa, and certainly testifies to North-South dispersal across the Mediterranean at some time during the early Pleistocene.
\end{abstract}

Keywords:

Mammalia 
Carnivora

Felidae

Mustelidae

Pleistocene

Mediterranean area

Biogeography

\section{Introduction}

The site of Tighennif (also known as Ternifine, and formerly called Palikao), in northern Algeria (N 35²4'55", E $\left.0^{\circ} 19^{\prime} 17^{\prime \prime}\right)$, was discovered in 1872. Pomel (1878) gave the first report on fossil finds; he also briefly described as Hyaena spelaea the first fossil carnivore from this site (Pomel, 1897), and reported a zorilla (striped polecat) skull, while correctly noting that it was probably not fossil. Many more fossils were discovered during the last part of the $19^{\text {th }}$ century. The great antiquity of the site was definitely established by the discovery by Pallary in 1928 of a canine of the saber-tooth cat Homotherium. Arambourg led new excavations in 1931, but the largest ones were conducted by C. Arambourg and R. Hoffstetter from 1954 to 1956 . Thousands of fossils were collected, together with numerous Acheulean artefacts and several human remains. Although these authors reported about their excavations and described the hominin remains (Arambourg and Hoffstetter, 1963), they left aside the other mammalian remains.

Two short field campaigns were conducted by a team led by J.-J. Jaeger et J.-J. Hublin in 1982-83; they resulted in an updated faunal list and a refinement of the stratigraphy and sedimentary context (Geraads et al., 1986). The bulk of the sediments consists of loose eolian sands, often rubefied, which overlie grey and varicoloured clays. All of these are fossiliferous; Arambourg did not record the origin of the fossils, but it can sometimes be deduced from their facies. A preliminary paleomagnetic analysis showed that the polarity of the basal sediments is normal; this suggested the Brunhes normal epoch, because in 1985 younger middle Pleistocene sites in Morocco were thought to be in the 200-300 ka range. As they now turn out to be significantly older, it is becoming clear that Tighennif is probably older than the middle Pleistocene, in agreement with overall similarity of the ungulate fauna with, e.g., those of Olduvai Beds III-IV, with the results drawn from the analysis of the arvicolid rodent Ellobius (A. Tesakov, pers. comm.), and with the cultural stage of the lithic industry (R. Gallotti, pers. comm.). Whether Tighennif belongs in fact to the Jaramillo subchron, or to 
an earlier period (assuming that the preliminary paleomagnetic results were not reliable) remains to be determined.

Only part of the fauna has been already published: Hominidae (Arambourg and Hoffstetter, 1963), Cercopithecidae (Delson and Hoffstetter, 1993; several unpublished limb bones of Theropithecus were also part of the "Carnivora" sample), ruminants (Geraads, 1981), Equidae (Eisenmann, 1981 and refs. therein), and rodents (Tong, 1986; Jaeger, 1988). The hominin, first called Atlanthropus mauritanicus, is a representative of the Homo erectus s.l. group, probably referable to Homo rhodesiensis Woodward, 1921 (Hublin, 2001).

Besides the carnivores, the updated faunal list of mammals includes: Homo cf. rhodesiensis, Theropithecus oswaldi, Loxodonta atlantica, Ceratotherium mauritanicum, Equus mauritanicus, Hippopotamus sirensis, Metridiochoerus compactus, Camelus thomasi, Giraffidae indet. cf. Mitilanotherium sp., Tragelaphus algericus, "Bos” bubaloides, Kobus sp., Oryx cf. gazella, Hippotragus cf. gigas, Connochaetes taurinus prognu, Parmularius ambiguus, Gazella dracula, Gazella cf. atlantica, Gazella sp. B, Caprini indet., Erinaceidae indet., Lepus sp., Ellobius africanus, Paraethomys tighenifae, Arvicanthis arambourgi, Praomys eghrisae, Gerbillus major, Gerbillus cingulatus, Mascaramys medius, and Meriones maximus.

\section{Material and methods}

The bulk of the Tighennif collection is housed in the Muséum National d'Histoire Naturelle (MNHN), Paris; a much smaller collection is housed in the Institut de Paléontologie Humaine (IPH), Paris, but it includes only one carnivore specimen. The Tighennif carnivores can be compared to modern forms and to those of some other North African localities, the main one being the Plio-Pleistocene site of Ahl al Oughlam, Morocco (Geraads, 1997, 2004). Late early to middle Pleistocene sites are rare, the main ones being part of the Thomas-Oulad Hamida complex of quarries in Casablanca (Geraads and Bernoussi, 2016), with the sites of "Grotte des Rhinocéros" (OH1-GDR) dated to $c a$. $0.5 \mathrm{Ma}$, and the Hominid cave of Thomas I (ThI-Hom) that is perhaps slightly older, ca. 0.6 Ma (chronology in Raynal et al., 1996). In addition, I have compared them to fossils from the Shungura Fm. of Ethiopia (MNHN and National Museum of Ethiopia, Addis Ababa: NME) and from the Koobi Fora Fm. of Kenya (National Museums of Kenya, Nairobi: KNM), as well as to some casts from the Hadar Fm. of Ethiopia.

Other abbreviations: AP: antero-posterior; H: height; L: length; trig.: trigonid; W: width. Upper teeth are in uppercase, lower teeth in lowercase. Measurements are in $\mathrm{mm}$. 


\section{Systematic palaeontology}

Order Carnivora Bowdich, 1821

Sub-order Feliformia Kretzoi, 1945

Family Hyaenidae Gray, 1821

Genus Crocuta Kaup, 1828

Crocuta crocuta (Erxleben, 1777)

Fig. 1(I, J)

Measurements: see Tables 1, 2.

Description: The spotted hyena is one of the most common carnivores at Tighennif. TER-

2159 is a distorted skull with full dentition, from the grey clay. Its most noticeable character is the lack of M1, a tooth that is variably present in the modern form. It is likely that P3, in middle wear, was not very tall, but other features are similar to those of the modern spotted hyena. Other remains of upper teeth are quite rare (Table 1).

Several mandibles (Fig. 1(I, J)), mostly from the clays, are of homogeneous overall size (the length $\mathrm{p} 2-\mathrm{m} 1$ ranges from 80.5 to $85 ; \mathrm{N}=6$ ). The third incisor is by far the largest; the central ones are reduced, and shed on TER-2152, which is not from an old individual. The p2, inserted about $1 \mathrm{~cm}$ behind the canine, is quite variable in size (Table 2). The mesial cristid may form an incipient mesial cuspid, but maximum width is at the level of the strong distal accessory cuspid. The cervix of $\mathrm{p} 3$ is not much deeper in the jaw than those of $\mathrm{p} 2$ and p4; the virtually unworn p3 TER-2214 is only slightly lower than in the modern form, but that of TER-2151 was certainly lower. The p3s have no mesial cuspid, and most of them are not broader mesially than distally, but the crown is always mesiobuccally expanded, so that these teeth are longer buccally than lingually. The $\mathrm{p} 4$ has at most a small mesial cuspid that may be vestigial; Eight out of $10 \mathrm{~m} 1 \mathrm{~s}$ lack a metaconid, but it is present on TER-2158 (Fig. 1(J)) and on TER-2184 as a minute cuspid appressed to the distal edge of the protoconid. The talonid usually consists only of the hypoconid, except on TER-2152 that has a vestigial entoconid. The paraconid, also as in the living form, is much longer than the protoconid (except in TER2185); it is bordered by a lingual cingulum.

Remarks: The p3s are distinctly more derived than those of $C . d b a a$ from Ahl al Oughlam (and those of the closely related C. dietrichi from East Africa) in being much broader than $\mathrm{p} 4$. However, the teeth of TER-2151 look more primitive in being relatively narrow, especially the distal part of $\mathrm{p} 3$. The modern form displays the same variation of $\mathrm{p} 4$ morphology. The metaconid of $\mathrm{m} 1$ is also rare in modern C. crocuta, but this cuspid is present in C. dbaa. 
Tooth measurements are very similar to those of the modern form (Table 2). A principal component analysis shows that the measurements of most of the Tighennif lower tooth-rows fall within the cloud of modern $C$. crocuta, in contrast to many earlier specimens of the Crocuta lineage, but variation is great, both in fossil and modern forms (Fig. 2).

Genus Hyaena Brisson, 1762

Hyaena hyaena (L.)

Fig. 1(K)

Measurements: see Table 3.

Description: This species is much less common than $C$. crocuta. It includes a maxilla TER2161 (Fig. 1(K); Table 3), a P3 TER-2164, a p4 TER-2165 (19.2 × $10.7 \mathrm{~mm})$, and a m1 TER$2162\left(\mathrm{~L}=22.2 \mathrm{~mm} ; \mathrm{W}=11.6 \mathrm{~mm} ; \mathrm{L}_{\text {trigonid }}=17.7 \mathrm{~mm}\right)$. Measurements of the upper teeth are very similar to the mean values of modern H. hyaena, and to a maxilla from the early middle Pleistocene site of OH1-GDR (Geraads and Bernoussi, 2016). These teeth display no morphological difference with the modern form.

As a rule at Tighennif, postcranials are quite rare by comparison with teeth, and this is especially true for the Hyaenidae. There is a distal humerus TER-2268, an incomplete ulna TER-2301, a complete Mc II TER-2255, and three incomplete metapodials TER-2259, TER2260, and TER-2278. Only the Mc II can be definitely identified as Crocuta, being more robust than those of $H$. hyaena $(\mathrm{L}=76 \mathrm{~mm}$; distal $\mathrm{W}=14.3 \mathrm{~mm})$.

Remarks: Tighennif unambiguously documents the co-occurrence of Hyaena and Crocuta. This co-occurrence has been reported in some later sites, but sometimes from different levels or in composite lists; old identifications are difficult to check, and some are certainly incorrect. Hyaena is less common than Crocuta, but it is the only hyena present in Djebel Irhoud (Amani, 1991; Amani and Geraads, 1993). Co-occurrence is definitely documented in the early middle Pleistocene of OH1-GDR (Geraads and Bernoussi, 1996), and in the upper Pleistocene of Sidi Bouknadel (Amani, 1991) and Boulevard Bru in Algiers (Pomel, 1897).

Family Felidae Fischer de Waldheim, 1817

Genus Felis L.

Felis silvestris Schreber, 1778

Fig. 3(E, F)

Measurements: see Table 4. 
Description: A maxilla TER-2022 (Fig. 3(E, F)) belongs to a Felis similar in size and morphology to modern wild cats (Table 4). The missing P2 was single-rooted; P3 has a high main cusp followed by a posterior accessory cusp closely appressed against it, and a thick cingulum; P4 has a short parastyle and a distinct, rounded ectoparastyle, a paracone as high as the P3 main cusp, and a robust, anteriorly located protocone. A P4 TER-2034 (L = $11.6 \mathrm{~mm}$; $\mathrm{W}=5.4 \mathrm{~mm}$ ) displays the same characters. Two lower m1s, TER-2027 and TER-2028 (Table 4) have a concave posterior edge, and no remnant of the metaconid/talonid complex; their dimensions fall within the range of modern African wild cats $(\mathrm{L}=6.3-9 \mathrm{~mm}, \mathrm{~W}=2.9-4 \mathrm{~mm}$; $\mathrm{N}=18$ ). A few felid postcranial elements are of the right size for this species. These are a proximal humerus TER-2281, a distal humerus TER-2283, a proximal tibia TER-2224, a distal tibia TER-2226, and an astragalus TER-2267.

Remarks: None of these features differ from those found in F. silvestris s.l. (i.e., including F. lybica), and I include these specimens in the modern species, whose taxonomy at species and subspecies level remains debated. A very similar form is already present at Ahl al Oughlam (Geraads, 1997), although the $\mathrm{m} 1$ from this site is slightly thicker than in modern African forms; a small Felis is also present at OH1-GDR (Geraads and Bernoussi, 2016). The earliest African Felis, from the late Miocene of Chad, is also of similar size (Peigné et al., 2008).

Genus Lynx Kerr, 1792

Lynx sp.

Fig. 3(A-D)

Measurements: see Table 4.

Description: This is the most common felid at Tighennif, with three mandibles and about 25 reasonably complete isolated teeth (Table 4). The five upper canines are moderately curved, and bear clear labial grooves. The only upper cheek teeth are two isolated right P4s, TER2033 and TER-2040. They have no ectoparastyle; the paracone is short; the protocone is small and almost fused to the base of the paracone, being demarcated from it by a shallow groove. The metacone is slightly shorter than the paracone.

The mandibles (Fig. 3(A-D)) are very homogeneous in size and morphology, so that there is no doubt that they are conspecific, and it is more parsimonious to assume that they are also conspecific with the upper carnassials, with which they agree in size. There are two mental foramina, one below the middle of $\mathrm{p} 3$, and one just behind the root of the canine; the masseteric fossa is deep anteriorly, with a sharply defined border just behind $\mathrm{m} 1$. Both the 
incomplete canine that is present on TER-2021 and an isolated lower canine TER-2046 have labial grooves, as in most modern felids. The diastema is short. The premolars have high main cuspids and very strong accessory ones; all p3s have a distinct anterior one. On $\mathrm{m} 1$, the metaconid is at most vestigial, and completely absent on three of the 10 teeth on which this region is preserved.

Postcranial elements that could belong to this species are two proximal ulnae TER2223 and TER-2288, a distal tibia TER-2225, two calcanei TER-2265 and TER-2266, two Mc V TER-2262 and TER-2263, and an incomplete Mt IV TER-2264. The ulnae have a long, narrow olecranon; the two tubercles that border the groove for the triceps tendon are rounded and unequal in size, as in lynxes; in C. caracal they are thinner and of similar size.

Remarks: In size and dental proportions this species is comparable to the modern African Leptailurus serval or Caracal caracal, but its lower premolars differ in their stronger accessory cuspids: the length of the main cuspid of $\mathrm{p} 4$ is at most half that of the whole tooth, whereas it is distinctly longer in these modern species. In addition, in the serval and caracal, the mental foramina are located more posteriorly, one below the posterior part of p3 and one just in front of this tooth (there is little variation in this feature), and the masseteric fossa smoothly merges into the corpus anteriorly. Further differences are that the caracal has smooth canines, and that the serval is somewhat smaller.

The modern northern lynx, Lynx lynx, resembles the Tighennif species in the location of the mental foramina, but it differs in the weaker premolar accessory cuspids, and long $\mathrm{m} 1$ relative to p4 (Werdelin, 1981: fig. 21). Among small lynxes, the Spanish L. pardinus and the middle Pleistocene L. thomasi Geraads, 1980, from Morocco, also have long m1s (very probably a derived feature, as assumed by Werdelin, 1981), but this difference with the Tighennif form is absent in some other fossil lynxes, and in the modern American L. rufus, whose dentition can be very similar in morphology and size to the Tighennif ones (Werdelin, 1981: fig. 21). The mandible and premolars of L. thomasi are also morphologically similar to those of the Tighennif form, although smaller. Unfortunately, we do not know whether the P2 was missing, as it is in lynxes, but the definite similarities that the Tighennif medium-size felid shares with small lynxes, by contrast with other similar-sized felids, strongly support its assignment to this genus.

The systematics of Pleistocene European lynxes has recently been simplified by Boscaini et al. (2016) who regard L. spelaeus as a synonym of L. pardinus, following Werdelin (1981). The form from Cueva Victoria in Southern Spain, roughly contemporaneous with Tighennif, displays the same main features, including the position of the mental 
foramina, rather short diastema, strong accessory cuspids on the premolars, occasional presence of the metaconid on $\mathrm{m} 1$, but is somewhat larger $\left(\mathrm{L}_{\mathrm{m} 1}=12.9-14.6 \mathrm{~mm}\right.$; Boscaini et al., 2016); this could just be an effect of Bergmann's rule and it is likely that the two populations are closely related.

In Northern Africa, besides L. thomasi, the genus could have been present in the PlioPleistocene of Ahl al Oughlam (Geraads, 1997) and in another (now destroyed) cave of unknown age in the Oulad Hamida area, but it seems that the genus never reached farther south (leaving aside the purported lynx from Langebaanweg described by Hendey, 1974, of doubtful identification). The time gap (0.5 m.y.?) between Tighennif and the fissure fillings of Oulad Hamida 1 Quarry, with L. thomasi, looks too short to assume a direct phylogenetic link between them, especially as this latter species has a much longer $\mathrm{m} 1$ than the Tighennif form, and the latter probably results from another, earlier dispersal from the Palearctic region. The similarities between the Cueva Victoria and Tighennif lynxes suggest that it was perhaps not much earlier than ca. $1 \mathrm{Ma}$; alternatively, it may date back to the Pliocene if the Ahl al Oughlam form, known by a single humerus, is really a lynx.

Felidae gen et sp. indet.

Measurements: see Table 4.

Description: This species is represented by two specimens only: an incomplete m1 TER-2026 lacks the posterior part so that the presence of a metaconid and talonid cannot be ascertained, but it was distinctly longer than in the previous species (Table 4); an incomplete P3 TER2035 has a strong anterior accessory cusp and a tall posterior one, but the tooth was broader than in Acinonyx. This species is the size of a small cheetah, but I shall not attempt identification at the genus level.

Genus Panthera Oken, 1816

Panthera aff. leo (L.)

Fig. 3(J-L)

Measurements: see Tables 4, 5.

Description: The material includes: TER-2173, a mandible fragment with p3, p4, and most of m1 (Fig. 3(K, L)); TER-2180, a mandible with most of m1; TER-2181, an incomplete P3; TER-2177 and TER-2178, two lower canines; TER-2174, 2175 and 2176, three upper canines (the first two probably of the same individual). These specimens belong to a lion-sized felid (Table 4). On both mandibular specimens, the diastema is short, there is no p2, and the p4 was 
almost certainly longer than $\mathrm{m} 1$, as may occur in large Panthera, but in contrast to other similar-sized large felids, like Dinofelis. The upper canines have lingual and labial grooves; the lower ones, which are of very different sizes, perhaps because of sexual dimorphism, have labial grooves only.

The ventral border of the corpus of TER-2180 is slightly convex. The premolars are missing but, from the size of their alveoli, their proportions were similar to those of lions. The posterior root of $\mathrm{p} 4$ is distinctly larger than the anterior one, as in lions. The $\mathrm{m} 1$ has a vestigial posterior complex, consisting of the very reduced metaconid and talonid, also as in lions.

On TER-2173, the p3 is similar to those of lions, but p4 is remarkably different. The anterior root is much stronger than the posterior one, which is slanting mesially. The anterior cuspid curves mesio-lingually, so that the mesial border of the tooth is almost straight and slanting mesio-lingually in occlusal view; this anterior cuspid is distinctly longer than the whole posterior lobe, which is unexpanded and has a much reduced posterior cingulum.

In addition, TER-2298 (Fig. 3(J)) is the distal portion of a left humerus, and TER-2297 is a complete left radius that could be from the same individual. There are several metapodials of homogeneous size and proportions (Table 5), and I tentatively assign to the same species a large, robust femur TER-2302, lacking most of the great trochanter and the distal epiphysis (estimated overall length $=350 \mathrm{~mm}$; proximal width $=90 \mathrm{~mm}$; AP diameter of head $=$ $42.5 \mathrm{~mm} ; \mathrm{W} \times$ AP diameter of shaft $=36 \times 32.5 \mathrm{~mm}$ ).

Remarks: In modern Panthera, the anterior lobe of p4 is shorter than the posterior one and has a rounded mesial border; an approach to the morphology of TER-2173 can occasionally be seen (especially in tigers) but no modern form has such a large anterior lobe. The posterior lobe of modern Panthera consists of an accessory cuspid plus a large cingulum that is expanded lingually and medially, thus greatly increasing the width of the tooth.

It is hard to decide whether the two mandibles described above are of the same species. It is unlikely that two lion-sized Panthera-like forms were present, but the difference in relative size of the $\mathrm{p} 4$ roots exceeds the lion variation. It is best to consider TER-2173, and tentatively refer the other specimens to the same species.

The short diastema and long premolars show that we are not dealing with Dinofelis, and the affinities of this form clearly lie within Panthera. Large forms of this genus are rare in the African Pleistocene. From Olduvai Bed II, Petter (1973) described as Pa. leo a mandible very similar to those of modern lions. From an unknown member of the Koobi Fora Fm., Werdelin and Lewis (2013) described as Pa. leo a mandible (KNM-ER-44267) whose p4 is as long as in lions, and has a strong mesial accessory cuspid, but not as large as that of TER- 
2173. A large Panthera is also present at Omo, but the material consists mostly of isolated teeth; no p4 resembles that of TER-2173. In the younger sites of ThI/OH1, no felid reaches the size of a lion.

In Europe, a large Panthera is documented in many sites of this period. Hemmer et al. (2003) called it $P$. onca gombaszogensis, regarding it as close to the American jaguar, and to the earlier $P$. toscana. Indeed, Hemmer et al. $(2003,2010)$ convincingly showed that the long p3 of this form demonstrates affinity with the jaguar rather than with other modern felids. In its very short p3, TER-2173 definitely differs from jaguars, this tooth being even shorter relative to $\mathrm{p} 4$ than in lions. However, Hemmer et al. (2010) described as P. onca georgica an earlier European jaguar from Dmanisi, characterized by a narrow p4, lacking "a broadened heel-shelf", and with a strong anterior cuspid, although not as large as that of TER-2173 (Hemmer et al., 2010: fig. 1). These are resemblances with TER-2173.

I have compared the distal humerus and complete radius with a good sample of modern $\mathrm{Pa}$. leo and $\mathrm{Pa}$. tigris (29 specimens in all), and with a reasonably good sample of Homotherium and Dinofelis in the MNHN and KNM. Their measurements are close to the maximum for modern Panthera, but they are much more similar to this genus than to Homotherium or Dinofelis. The clearest difference with machairodonts concerns the medial epicondyle, which is more robust and located much more caudally in Panthera, so that the bar that bridges the entepicondylar foramen and ends into the epicondyle is oblique distocaudally, instead of being proximo-distally oriented as in Homotherium. In addition, as noted by Werdelin and Lewis (2001), the trochlea of Panthera is broader relative to its diameter than in Dinofelis, and still more so than in Homotherium; that of TER-2298 is very broad. Thus, this humerus definitely belongs to Panthera, but the entepicondylar foramen is mesiodistally longer than in modern $\mathrm{Pa}$. leo, and much longer than in machairodonts. The complete radius TER-2297 is larger than in Dinofelis, but its proportions and general shape are similar, although it is perhaps less curved (Werdelin and Lewis, 2001: figs. 11(D-E), 16(C)) and clearly more massive than in Homotherium (e.g., Ballésio, 1963: fig.27; Werdelin and Lewis, 2013: fig. 8.4). In spite of its large size, at the distal end, the ridges bordering the grooves for the extensors are remarkably blunt, contrasting with the sharp ridges of Dinofelis, Homotherium (Werdelin and Lewis, 2013: fig. 8.4), and even of Panthera, but it otherwise differs little from this latter genus.

The metapodials are more robust than those of Homotherium (Werdelin and Lewis, 2001: fig. 41) and slightly more robust than those of modern lions, but they remain much smaller than those of some middle Pleistocene European lions (e.g., Argant, 1991: table 76; 
Barycka, 2008: figs. 47, 49, 65). There are two right Mt IV, so that at least two individuals are represented. These Mt IV are very different from those of Homotherium in that the proximal head is strongly shifted laterally, so as to overhang the Mt V, as in Panthera; in Homotherium (Ballésio, 1963: fig. 56) and Dinofelis (Werdelin and Lewis, 2001: fig. 20(C)) the bone is much straighter.

I have compared the femur with casts of femora Omo 71-1491 and F-267-1 from the Omo Shungura Fm., and AL 185-29 from Hadar. The latter two specimens were identified as Homotherium by Werdelin and Lewis (2013), while the former one is also identified as such in the Omo catalogue. TER-2302 shows a mixture of Homotherium and Panthera characters that make it hard to identify. The great trochanter was higher than the head, in contrast to these fossils, but as in Pa. leo and H. crenatidens from Senèze (Ballésio, 1963: fig. 45). In contrast to these fossils again, but as in ER 2092 from the Upper Burgi Mb. of the Koobi Fora Fm., assigned to Homotherium sp. by Werdelin and Lewis (2013), the intertrochanteric fossa does not extend close to the lesser trochanter, which is located more medially than in all these African forms, but as in $\mathrm{H}$. crenatidens and $\mathrm{Pa}$. spelaea. Perhaps the most noticeable feature of TER-2092 is its extremely strong lateral crest, extending almost to the distal epiphysis, and reminiscent of the Koobi Fora specimen (Werdelin and Lewis, 2013).

The material of the large Panthera of Tighennif is insufficient for elucidating its precise affinities, or for erecting a new species, but it is likely distinct from $\mathrm{Pa}$. leo. It might be related to $P$. onca georgica, assuming that the short $\mathrm{p} 3$ of TER-2173 by comparison with the Dmanisi form is related to the lengthening of its $\mathrm{p} 4$. It might instead be descended from the large felid represented at Ahl al Oughlam (Geraads, 1997) by a single humerus that resembles the Tighennif one, but drawing definite conclusions from this incomplete material would be highly speculative.

Genus Homotherium Fabrini, 1890

Homotherium sp.

Fig. 3(G-I)

Measurements: see Table 4.

Description: Several specimens can be assigned to a sabre tooth cat. An incomplete upper canine F-3994, collected by Pallary, is housed in the IPH (Paris); part of the crown is missing, but both edges of the crown are serrated. TER-2167 is a snout fragment with I3 and the upper canine, separated by a very short diastema. The teeth are poorly preserved, but the canine is distinctly crenulated along its distal edge. TER-2168 is another, incomplete, smaller upper 
canine, also serrated. These canines are strongly compressed transversally (measurements: perpendicular $\mathrm{AP} \times$ transverse diameters of the upper canines: TER-2167 $=28.5 \times 11.5 \mathrm{~mm}$; TER-2168 $=26.5 \times 10.7 \mathrm{~mm}$; IPH F-3994 = $26 \times 11.6 \mathrm{~mm})$. They are all strongly curved. None of them allows to infer whether it contacted the lower canine or not. Interestingly, the canine of TER-2167 was broken in life, and subsequently worn; such breakage is common in Smilodon (Binder and Van Valkenburgh, 2010), which is not unexpected given the shape of this tooth, but how these predators were able to survive with a broken canine remains an open question.

TER-2171 is a p3, and TER-2172 a p4, probably of the same individual (Fig. 3(G-I); Table 4). Both are distinctly crenulated along their main edge. The p3 has only a weak posterior accessory cuspid, its roots are almost completely fused into a single one, and this tooth is much reduced relative to $\mathrm{p} 4$. The roots of $\mathrm{p} 4$ are slanting anteriorly; the tip of the posterior accessory cuspid is broken off, but no distinction can be made between the cuspid itself and the cingulum on the buccal side. In addition, there is an upper I1 or I2 TER-2170, and a lower one TER-2169.

Remarks: Canines as strongly compressed as the Tighennif ones can be found as early as the late Miocene, so that this typically machairodontin character is of little help to elucidate the affinities of the Tighennif form. The geographically closest form is the one from the earliest Pleistocene of Ahl al Oughlam (Geraads, 2008), but at Tighennif the canines are more curved, and the p4 (AaO-3197), which is otherwise similar in size and morphology (Geraads, 1997), has only a small distolingual cuspid-like expansion, more like a p4 from Sterkfontein (Turner, 1987: fig.4).

The strong reduction of $\mathrm{p} 3$ is characteristic of Pleistocene Homotherium: a ratio $\mathrm{L}_{\mathrm{p} 3} / \mathrm{L}_{\mathrm{p} 4}$ not exceeding 0.5 is known only at Nihowan (Teilhard de Chardin and Piveteau, 1930), Roccaneyra (Bonis, 1976), Senèze (Ballésio, 1963), and in mandible KNM-ER 931 from above the KBS tuff at Koobi Fora (Werdelin and Lewis, 2013). What is known of the Tighennif Homotherium does not differ from European $H$. crenatidens, whose last representatives are contemporaneous, but such an identification would assume a phyletic relationship that remains undemonstrated. Given the present confusion regarding the taxonomy of the genus, I shall not attempt species identification of these few remains, which document the latest sabre-tooth cat in Africa.

Sub-order Caniformia Kretzoi, 1943

Family Ursidae Fischer de Waldheim, 1817 


\section{Genus Ursus L.}

Ursus aff. bibersoni Ennouchi, 1957

Fig. 1(H)

Measurements: see Table 6.

Description: Bears are represented by rare pieces (Table 6). The only complete tooth is a relatively broad P4 (TER-2003); the paracone is much larger than the metacone; the protocone is large, well distinct, larger than the metacone, and unconnected to the other cusps, but it proceeds distally into a cingulum; there are no accessory cusps. TER-2001 (Fig. 1(H)) is a mandible with worn and very incomplete $\mathrm{m} 1$ and $\mathrm{m} 2$. In spite of the old ontogenic age, the corpus is remarkably shallow, with a virtually straight ventral border, at least as far posteriorly as the middle of the masseteric fossa, which does not extend far ventrally. Nothing can be said about the tooth morphology, except than the central constriction of $m 2$ is weak. The alveolus of $\mathrm{m} 3$ is well preserved, and allows a good estimate of the length of this tooth, which was certainly much shorter than $\mathrm{m} 2$. This is confirmed by a toothless mandibular fragment TER-2002 that also shows a short $\mathrm{m} 3$ alveolus. An incomplete, unregistered calcaneus is the only postcranial ursid remain.

Remarks: The P4 resembles $U$. arctos and the North African middle Pleistocene bears called U. bibersoni (Ennouchi, 1957: pl.7, fig.10; Geraads and Bernoussi, 2016); although there is variation in the size of this cusp, the protocone is usually smaller in European middle Pleistocene forms, and the tooth is therefore narrower (Prat and Thibault, 1976: table 33; Baryshnikov, 2006: table 1). In the mandible of European forms, the ventral border starts curving upwards more anteriorly, the corpus is deeper, and the masseteric fossa extends farther ventrally. The shallow corpus with straight ventral border of the Tighennif form resembles more bears of the arctos group and U. bibersoni (Ennouchi, 1957: pl. 6) than the speleoid $U$. deningeri. The short $\mathrm{m} 3$ is a primitive character, contrasting with the lengthened $\mathrm{m} 3 \mathrm{~s}$ of $U$. spelaeus in Eurasia and of $U$. bibersoni in North Africa, in which $\mathrm{m} 3$ becomes almost as long as $\mathrm{m} 2$. In contrast to the latter species, which has narrow teeth, the $\mathrm{m} 2$ of TER2001 is broad, as in Eurasian forms.

The history of bears in North Africa begins in the Plio-Pleistocene of Ahl al Oughlam (Geraads, 1997), but their evolution remains poorly understood, because the documentation is sparse before the late Pleistocene. The scrappy material from Tighennif does not contribute much to this history, but it satisfactorily fits between the early Ursus from the latest Pliocene of Ahl al Oughlam (Geraads, 1997) and the middle Pleistocene U. bibersoni (Ennouchi, 1957; Geraads and Bernoussi, 2016). The latter species seems to belong to an endemic lineage 
whose characteristics (narrow teeth, slender mandibular ramus) might be linked with a soft, perhaps partly carnivorous diet. The Tighennif bear could be an early representative of this lineage, which might have branched soon after the split between the arctos and spelaeus branches (Rabeder, 2009), but the systematics and phylogeny of early to middle Pleistocene European bears is still confused (Olive, 2006; Wagner, 2010).

Family Mustellidae Fischer de Waldheim, 1817

Genus Mellivora Storr, 1780

Mellivora capensis Schreber, 1776

Measurements: see Table 7.

Description: The honey badger is represented by a braincase (TER-2013; Table 7), almost certainly from the same individual as an edentulous maxilla and a mandible (TER-2016) from the basal clays. The braincase is inflated, with a convex longitudinal profile and a long sagittal crest, and a twofold nuchal crest with a long, straight dorsal part. The infra-orbital foramen is double, and located above P3. There are also some isolated teeth: an upper canine (TER-2019; basal diameters: $8.5 \times 6.3 \mathrm{~mm}$ ), a P3 (TER-2018; $8.9 \times 6.8 \mathrm{~mm}$ ), and an unregistered, much worn $\mathrm{p} 4$.

Remarks: All cranial features are similar to those of the modern M. capensis, although the outline of its occipital is usually more rounded, less trapezoidal. African cranial remains are contemporaneous or younger. According to Ewer and Singer (1956) and Hendey (1974) the Elandsfontein form does not significantly differ from the modern one. The same is true for the skull from Asbole in Ethiopia (Geraads et al., 2004), and for an unpublished braincase from ThI-Hom. In spite of differences in proportions, it seems that they all fall into the variation range of the modern species. Lower teeth are large, and the premolars are much larger relative to $\mathrm{m} 1$ than in the Asbole specimen, but the $\mathrm{p} 4$ of TER-2016 is only marginally larger than in modern forms. However, as at Asbole, p4 has robust accessory cuspids, unlike M. benfieldi from Langebaanweg (Hendey, 1974, 1978) and the Mellivora of Ahl al Oughlam (Geraads, 1997), and these Pliocene forms differ from the Pleistocene ones in this regard. Thus, although species distinction between Pliocene and modern forms is certainly warranted, all Pleistocene ones seem to fall within the variation range of $M$. capensis.

Genus Poecilictis Thomas and Hinton, 1920

Poecilictis cf. libyca (Hemprich and Ehrenberg, 1833) 
Description: A small mustelid is represented by an unregistered P4, two unregistered M1s, and a mandible with $\mathrm{p} 3-\mathrm{m} 1$ (TER-2004). The $\mathrm{P} 4(\mathrm{~L}=6.3 \mathrm{~mm} ; \mathrm{W}=3.5 \mathrm{~mm})$ has a strong parastyle, a very large protocone directed antero-lingually and reaching much farther forward than the parastyle, and a relatively long metacone. The $\mathrm{M} 1 \mathrm{~s}(\mathrm{~L}=3.0$ and $2.8 \mathrm{~mm} ; \mathrm{W}=5.9$ and $5.9 \mathrm{~mm}$ ) are short and broad, trapezoidal, with parallel anterior and posterior borders, but with an expanded anterobuccal cingulum; the paracone is distinct from, and larger than the metacone; the posterolingual cusp is almost as large as the protocone. The mandible is wellpreserved, and similar to those of modern Ictonyx. The p4 $(3.9 \times 2.0 \mathrm{~mm})$ has a posterobuccal cuspid closely appressed against the main cuspid. The trigonid of $\mathrm{m} 1(6.5 \times 3.0 \mathrm{~mm})$ has a strong metaconid, but is not much broader than the talonid, which consists of a large hypoconid plus a distinct, although smaller and lower, entoconid; these cuspids are separated by a groove that opens distally; $\mathrm{m} 2$ is represented by its alveolus only.

Remarks: Systematics of the small African mustelids is still confused. Among modern forms, the North African Poecilictis libyca is morphologically very similar to the southern Ictonyx striatus, and these two species are now usually included in the same genus Ictonyx. However, on the basis of mitochondrial DNA analysis, Sato et al. (2012) concluded that the sister species of I. striatus is the South African Poecilogale albinucha, a conclusion that is hardly acceptable on a morphological basis, although there is no doubt that these three species form a clade distinct from Eurasian forms. The only named fossil form is Ictonyx bolti Cooke, 1985, first described from Bolt's Farm in South Africa (actually, Cooke's paper appeared in October 1985; the name was first mentioned by Petter and Howell in a paper that was published in April 1985 but that contains no indication that would make the name available). The species was made the type of the new genus Prepoecilogale by Petter and Howell (1985), and identified at Laetoli by Petter (1987, as Propoecilogale [sic.]). The species was later reported from Ahl al Oughlam (Geraads, 1997) and Cooper's (O'Regan et al., 2013). The description and illustration of the type specimen do not allow definite conclusions, but Cooke (1985) mentions that the protocone of $\mathrm{P} 4$ is at right angle to the blade: this is unlike the species from Laetoli (Werdelin and Dehghani, 2011: fig.8.8) and Ahl Oughlam (AaO-2821, 2822, 2823), which have a forwardly directed protocone, and whose referrals to " $P$." bolti now appear disputable. As I have not seen the type specimen of I. bolti, I shall refrain from concluding about its affinities, but the Ahl al Oughlam material is clearly quite close to I. striatus and P. libyca in its strong, forwardly directed $\mathrm{P} 4$ protocone, $\mathrm{m} 1$ with large metaconid and long talonid, and relatively large $\mathrm{m} 2$. Size differences suggest that two species are present at this site, but the largest and most common one resembles $P$. libyca more than I. striatus in its 
relatively broad $\mathrm{m} 1$ talonid, with large entoconid (AaO-1331). It is likely that the Laetoli species should be included in Ictonyx as well, rather than in Prepoecilogale.

In its overall size, long, forwardly directed P4 protocone, short M1 with distinct paracone and metacone and expanded mesio-buccal cingulum, strong $\mathrm{m} 1$ metaconid, and presence of $\mathrm{m} 2$, the Tighennif species is clearly also a member of the Ictonyx/Poecilictis group, and is remarkably similar to the Ahl al Oughlam form. Its broad $\mathrm{m} 1$ talonid with large entoconid is especially distinct from that of I. striatus, whose $\mathrm{m} 1$ sharply narrows behind the talonid, and whose entoconid consists only of an indistinct lingual ridge. The material is insufficient for definite identification, but species identity of the Tighennif mustelid with $P$. libyca is likely. It differs from the Laetoli form in its lower $\mathrm{p} 4$ with stronger accessory cuspid, and $\mathrm{m} 1$ with larger metaconid and longer talonid.

In addition, there are three mustelid P4 blades that are somewhat smaller than the above-mentioned specimen, with especially a shorter metacone. They might belong to another species, but I shall not attempt identification of these fragments. There is no conclusive evidence of small mustelids of northern affinities (e.g., Martes or Mustela).

Genus Enhydrictis Major, 1901

Type-species: Enhydrictis galictoides Major, 1901

Enhydrictis hoffstetteri nov. sp.

Fig. 1(A-E)

Derivation of the name: dedicated to Robert Hoffstetter (1908-1999), who excavated Tighennif with C. Arambourg.

Holotype: TER-2008, right mandibular corpus with c-m1; housed in MNHN, Paris (Fig. 1(AC)).

Diagnosis: a species of Enhydrictis of medium size, with a sectorial $\mathrm{m} 1$ talonid lacking an entoconid ridge.

Description: The mandibular corpus of the holotype is deep but not very thick; there are three mental foramina, below p2, p3, and p4. The canine is robust $(9.6 \times 6.2 \mathrm{~mm})$, especially its root; the crown is circled by a basal cingulum, and covered by deep wrinkles; a shallow mesio-lingual furrow extends down on the root. The premolars are narrow and slender. The p2 $(4.8 \times 3.4 \mathrm{~mm})$ is much smaller and inserted at a higher level than p3 $(6.5 \times 4.2 \mathrm{~mm})$; they have an oval occlusal outline, but no accessory cuspids. The $\mathrm{p} 4(7.6 \times 4.3 \mathrm{~mm})$ has a minute anterior accessory cuspid, and a shoulder-like incipient cuspid on the ridge descending 
distally from the main cuspid. It largely overlaps $\mathrm{m} 1$ in lateral view, but its posterior root is more ventral and more buccal than the anterior root of $\mathrm{m} 1$. The trigonid of $\mathrm{m} 1(13.7 \times$ $5.7 \mathrm{~mm}$ ) is widely open, with a long, antero-posteriorly oriented paraconid, and a small metaconid located more distally than the protoconid. The talonid is long, but remains much shorter and slightly narrower than the trigonid. It consists mostly of a hypoconid ridge whose lingual slope almost reaches the lingual border of the tooth, leaving almost no central valley. The entoconid is reduced to an indistinct, low ridge. There is a faint buccal cingulum along the paraconid, but almost none elsewhere. The corpus is broken behind $\mathrm{m} 1$.

I assign to the same species three unregistered M1s $(5.5 \times 9.6,5.5 \times 9.7,5.5 \times 9.9 \mathrm{~mm}$ - this latter tooth is from the right side, and could be from the same individual as one of the other two, left teeth) of very homogeneous size and morphology (Fig. 1(D, E)). They are short and broad, and assume the shape of a parallelogram, with parallel mesial and distal borders, and also parallel, disto-lingually oblique buccal and lingual ones. The paracone is slightly larger than the metacone, located more buccally, and bordered by a strong buccal cingulum. A deep valley separates those cusps from a protocone whose preprotocrista forms a minute protoconule before it dwindles into the mesial margin, but lacks a postprotocrista; the hypocone protrudes distolingually but remains unexpanded.

Remarks: This mustelid somewhat resembles otters, but differs in important features. The corpus is somewhat deeper, and the canine more robust and more wrinkled, but the main differences are in the shape of the molars. In modern Lutra and Hydrictis the M1 is longer relative to its width, so that it appears less stretched mesio-buccally to disto-lingually, the metacone is less reduced, and the hypocone is more expanded. On m1, the trigonid angle is always much less open, with a paraconid directed more lingually (even in L. lutra, which has the most forwardly directed paraconid), and a metaconid that is larger and located only slightly more distally than the protoconid; in addition, the talonid is larger, and as broad or even broader than the trigonid. The same features characterize fossil African otters such as L. fatimazohrae Geraads, 1997 from Ahl al Oughlam, L. hearsti Geraads et al., 2015 from Dikika, H. gudho Werdelin and Lewis, 2013 from Koobi Fora (as far as the heavy wear of the type-specimen allows observations), or the so-called Torolutra Petter et al., 1991, identified from a number of sites in Uganda (Petter et al., 1991), Kenya (Werdelin and Lewis, 2013), and Ethiopia (Haile-Selassie, 2008). The otter that most closely resembles TER-2008 is KNM-ER 4568 from the Upper Burgi Mb. of the Koobi Fora Fm. (Werdelin and Lewis, 2013), but even this specimen has the typical lutrine morphology of the $\mathrm{m} 1$ trigonid. 
It is clear, therefore, that the Tighennif large mustelid cannot be identified with any previously known African form, and comparisons must be extended to Eurasia, where similarsized mustelids have been reported under various names, and included in the genera Enhydrictis Major, 1901, Mustelercta Gregorio, 1925, Pannonictis Kormos, 1931, and Eirictis Qiu, Deng, and Wang, 2003. They are known from the "Villafranchian" of VillányKalkberg, Hungary (Kormos, 1931), Perrier-Etouaires and Saint-Vallier, France (Schaub, 1949; Viret, 1954), Tegelen, Netherlands (Schreuder, 1935; Willemsen, 1988), Wölfersheim, Germany (Morlo and Kundrat, 2001), Deutsch-Altenburg, Austria (Rabeder, 1976), Pietrafitta, Pirro Nord, Upper Valdarno, and Monte Pellegrino, Italy (Rook, 1995; Burgio and Fiore, 1997; Colombero et al., 2012), Varshets, Bulgaria (Spassov, 2003), Liventsovka, Ukraine (Sotnikova et al., 2002), Palan-Tyukan, Azerbaijan (Sotnikova and Sablin, 1993), and as far East as Shamar (Sotnikova, 1980), Nihowan (Teilhard de Chardin and Piveteau, 1930), and Longdan (Qiu et al., 2003). Their latest continental record in Europe seems to be Atapuerca, Spain (García and Howell, 2008), but they still occur much later in Sardinia (Major, 1901; Ficcarelli and Torre, 1967).

Systematics of these forms is disputed, and beyond the scope of this paper, but they share with the Tighennif mustelid the same short, broad, obliquely stretched M1 (e.g., Rabeder, 1976: pl. 6, fig.13); a large, wrinkled lower canine with a mesio-lingual groove; simple, crowded lower premolars; a very open m1 trigonid with moderate metaconid; a large $\mathrm{m} 1$ talonid in which the hypoconid is by far the largest cuspid, with a large, flat lingual slope. There is some variation in the shape of the $\mathrm{m} 1$ talonid, i.e., in the development of the entoconid ridge and the depth of the talonid basin, but they are always well indicated, although perhaps less conspicuous in the mandible that is probably part of the type specimen of E. galictoides (Naturhistorisches Museum Basel Ty 11479), but its teeth are worn and imperfectly preserved. García and Howell (2008) also stated that at Atapuerca "The talonid [...] lacks entoconid or hypoconulid and bears only hypoconid on the buccal side", but an entoconid ridge is visible in their figures. Therefore, I regard the absence of this ridge on the Tighennif $\mathrm{m} 1$ as a clear distinctive feature.

Of course, the most interesting aspect of the occurrence of Enhydrictis in Algeria is biogeographic, as this genus (or cluster of genera - in case of synonymy, Enhydrictis Major, 1901 has priority) has never been reported so far from Africa. However, at a similar time period, Enhydrictis s.1. was present in southern Europe at Atapuerca in Northern Spain (García and Howell, 2008) and at Monte Pellegrino in Sicily (Burgio and Fiore, 1997), and there is little doubt that E. hoffstetteri nov. sp. is of European origin. The site of Monte 
Pellegrino, whose age is somewhat uncertain, contains mostly microvertebrates of European affinities but also the endemic ctenodactylid rodent Pellegrinia, which López-Antoñanzas et al. (2016) include within a clade consisting only of African forms, and which is therefore certainly of African origin. Stöck et al. (2008) also found probable exchange of toads between Tunisia and Sicily around the early Pleistocene. There is no doubt, therefore, that faunal exchanges occurred between Sicily and Africa at that time. Alternatively, Enhydrictis might have followed a western route, as definite Pleistocene exchange occurred through Gibraltar (Theropithecus). In any case, the good swimming abilities of many mustelids urges caution before concluding about the existence of a "land-bridge" at this time.

Family Canidae Fischer de Waldheim, 1817

Remarks: North African representatives of this family have recently been revised (Geraads, 2011), and detailed descriptions need not to be repeated here.

Genus Vulpes Frisch, 1775

Vulpes cf. rueppelli (Schinz, 1825)

Measurements: see Table 8.

Description: The material includes a left maxilla with P1 and P3-M2 (TER-2055; Geraads, 2011: pl.1, fig. 11), four P4s (TER-2075, 2077, 2078 and no \#), two unregistered M1s, an unregistered M2, and two m1s (TER-2122, $12 \times 4.8 \mathrm{~mm}$, and TER-2123, $10.8 \times 4.6 \mathrm{~mm}$ ). These specimens differ little from the modern V. rueppelli, except that their P4s are slightly smaller relative to M2; TER-2055 is close to the upper end of the size range of the modern form, but it is more parsimonious to include all these specimens in a single species. There is no definite evidence of $V$. vulpes, which entered Africa only later in the middle Pleistocene.

Genus Lupulella Hilzheimer, 1906

Lupulella mohibi Geraads, 2011

Fig. 1(F)

Measurements: see Tables 9, 10.

Description: The material consists of a right mandibular corpus with p4-m2 (TER-2057; Fig. 1(F)), a mandibular corpus with p3-m1 (TER-2058), and about 50 isolated teeth (10 P4s, 11 M1s, 7 M2s, 1 p4, $14 \mathrm{~m} 1 \mathrm{~s}$, and $10 \mathrm{~m} 2 \mathrm{~s}$ ). This species was defined at OH1-GDR, where its affinities remained mysterious until a complete skull was found. The large size of the crushing part of its dentition, including a trapezoidal M1 with a very strong hypocone and a 
continuous buccal cingulum, is strongly reminiscent of Nyctereutes but, unlike this genus, the mandibles lack a sub-angular lobe both at ThI/OH1 and Tighennif, showing that it is a true jackal.

Canid postcranials are quite rare. TER-2282 is a distal humerus, TER-2287 a proximal ulna, TER-2148 and TER-2147 associated astragalus and calcaneum, probably of L. mohibi, but a calcaneum (TER-2149) and a distal tibia (TER-2276) fit better into Vulpes.

Remarks: The morphology and relative proportions of the teeth from Tighennif do not differ from those of the younger sites of ThI/OH1; their mean dimensions are only slightly larger (Tables 9, 10). The fact that the teeth are still smaller in the later site of Sidi Abderrahmane (Geraads, 2011) suggest that the species, which is unknown outside North-Western Africa, decreased in size during the course of the middle Pleistocene, but this evolutionary change, if real, does not significantly alter the main characteristics of this remarkable species.

Genus Lycaon Brookes in Griffith et al., 1827

Lycaon magnus Ewer and Singer, 1956

Fig. 1(G)

Description: The material includes two upper right M1s, TER-2053 (L=16.7 mm, W = $18.6 \mathrm{~mm}$ ) and TER-2054 ( $\mathrm{L}=16.5 \mathrm{~mm}, \mathrm{~W}=17.5 \mathrm{~mm})$, unregistered P2 and P3 (Fig. 1(G)), and fragments of other teeth. The M1s (Geraads, 2011: pl.1, fig. 9) are long and relatively narrow, with a much reduced hypocone, and no paraconule. There is no postprotocrista, and the disto-buccal cingulum does not reach the metaconule. The two upper premolars (Fig. $1(\mathrm{G})$ ) have strong accessory cusps; they are about as broad mesially as distally, and P2 is distinctly longer than high.

Remarks: The morphology of the M1s resembles that of modern L. pictus, but differs from that of L. sekowei Hartstone-Rose et al., 2010, from the early Pleistocene of South Africa. By contrast, the long, low P2s differ from those of the modern lycaon, which is also slightly smaller, and resemble L. sekowei and the South African middle Pleistocene L. pictus magnus Ewer and Singer, 1956, which might have had a wide range in Africa. It looks sufficiently different from the modern form to warrant species distinction. This species is also present in the middle Pleistocene sites of Casablanca (Geraads, 2011).

\section{Discussion}

The total number of carnivoran specimens identified in Tighennif is summarized in Table 11. This is a rich fauna for a single site, and it is well balanced between the various 
families, although the smaller forms are certainly underrepresented because of taphonomic or collecting biases. The virtual absence of the leopard excludes a heavy wood cover (a conclusion strongly supported by the rest of the fauna), and the diversity of carnivores also excludes an extremely open environment (that the abundance of alcelaphin and antilopin bovids might have suggested), but it is hard to go far beyond this.

Compared to the Plio-Pleistocene fauna of Ahl al Oughlam (Geraads, 1997, 2004, 2008, 2011), perhaps 1.5 m.y. older, the most noticeable absences are those of Pliocrocuta and Chasmaporthetes, which went extinct in the meantime, but also those of Acinonyx, Herpestes, and Nyctereutes, which are not rare at Ahl al Oughlam. The latter genus was obviously replaced by Lupulella mohibi, which shares similar dental adaptations to omnivory, but the niche of medium-size to large felids is clearly less crowded than at Ahl al Oughlam, and the absence of Acinonyx is especially noticeable, given the open environment of the site. Still, there are a number of taxa that suggest phyletic continuity between the two sites: Crocuta dbaa - C. crocuta; "Hyaenictitherium" barbarum (a synonym of Ikelohyaena abronia according to Werdelin, pers. comm., but the type of this species is early Pliocene in age) - Hyaena hyaena, Felis cf. silvestris - F. silvestris; Lynx; Panthera aff. leo; Homotherium; Ursus; Mellivora; Poecilictis; Vulpes hassani - V. cf. rueppelli; and Lupulella paralius - L. mohibi. By comparison, there are only a few new lineages at Tighennif: Lycaon, perhaps of South African origin, and Enhydrictis that certainly came from Europe. As for many other mammalian groups, the scarcity of early Pleistocene faunas in North Africa seriously hampers our understanding of the evolution of carnivore assemblages at these time.

In terms of biogeography, Enhydrictis testifies to the persistence of transMediterranean exchanges that sporadically occurred since the Messinian (Geraads, 1998, 2010; García-Alix et al., 2016; Gibert et al., 2016). The lynx, which is certainly also of northern origin, could have followed the same route, but the date of its arrival in N. Africa is unknown - it may be as old as the Pliocene. These carnivore dispersals do not imply that humans followed similar routes, but at least they show that they existed. Still, it is clear that by the late Calabrian, in the absence of foxes (V. alopecoides/praeglacialis) and mustelids (Mustela, Martes, Meles) of northern type, in the disappearance of hyenas of the Pliocrocuta/Pachycrocuta group and their early replacement by Crocuta, and in the rarity of wolf-like canids (known only at Aïn Hanech; Geraads, 2011), the North African carnivore fauna remains quite distinct from the European one, and much closer to African ones, even though the lynx, Ursus, and Lupulella mohibi point to some isolation from areas further south. Whether the absence of these taxa in Eastern Africa results from their inability to cross the 
present-day Sahara, or to compete with species already established there remains unknown but, because many ungulates show that the Sahara was not a continuous barrier at that time (Geraads, 2010), I definitely favour the second alternative, except perhaps for the bear that probably required some significant wood cover and humidity.

\section{Acknowledgments}

Thanks to C. Argot (MNHN) for access to the Tighennif material, to J. Lesur and G. Véron (MNHN) for access to modern material, and to researchers who provided photos of fossils in various institutions: E. Cioppi (Firenze), S. Colombero (Torino), B. Mennecart (Basel), N. Spassov (Sofia). The manuscript benefited from helpful comments by

L. Werdelin, an anonymous reviewer, and the editors of Geobios. Many thanks also to P. Loubry for the photos.

\section{References}

Amani, F., 1991 La faune du gisement à Hominidés du Jebel Irhoud. Contribution à l'étude de la chronologie et de l'environnement du Quaternaire marocain. Thèse Université de Rabat (unpublished).

Amani, F., Geraads, D., 1993. Le gisement moustérien du Djebel Irhoud, Maroc : précisions sur la faune et la biochronologie, et description d'un nouveau reste humain. Comptesrendus de l'Académie des Sciences sér. II 316, 847-852.

Arambourg, C., 1979. Vertébrés villafranchiens d'Afrique du Nord (Artiodactyles, Carnivores, Primates, Reptiles, Oiseaux). Fondation Singer-Polignac, Paris.

Arambourg, C., Hoffstetter, R., 1963. Le gisement de Ternifine. Archives de l'Institut de Paléontologie Humaine 32, 1-190.

Argant, A., 1991. Carnivores quaternaires de Bourgogne. Documents des Laboratoires de Géologie de la Faculté des Sciences de Lyon 115, 1-301.

Ballésio, R., 1963. Monographie d'un Machairodus du gisement villafranchien de Senèze : Homotherium crenatidens Fabrini. Travaux du Laboratoire de Géologie de la Faculté des Sciences de Lyon 9, 1-129.

Barycka, E., 2008. Middle and late Pleistocene Felidae and Hyaenidae of Poland. Natura optima dux Foundation, Warszawa.

Baryshnikov, G., 2006. Morphometrical variability of cheek teeth in cave bears. Scientific annals, school of geology, AUTH 98, 81-102.

Binder, W.J., Van Valkenburgh, B., 2010. A comparison of tooth wear and breakage in 
Rancho la Brea sabertooth cats and dire wolf across time. Journal of Vertebrate Paleontology 30, 255-261.

Bonis, L. de, 1976. Un Félidé à longues canines de la Colline de Perrier (Puy-de-Dôme) : ses rapports avec les Félinés machairodontes. Annales de Paléontologie 62, 159-198.

Boscaini, A., Alba, D.M., Beltrán, J.F., Moyà-Solà, S., Madurell-Malapeira, J., 2016. Latest Early Pleistocene remains of Lynx pardinus (Carnivora, Felidae) from the Iberian Peninsula: Taxonomy and evolutionary implications. Quaternary Science Reviews 143, 96-106.

Burgio, E., Fiore, M. 1997. Mustelercta arzilla (De Gregorio,1886) elemento villafranchiano nella fauna di Monte Pellegrino (Palermo, Sicilia). Il Quaternario - Italian Journal of Quaternary Sciences 10, 65-74.

Colombero, S., Pavia, M., Rook, L., 2012. Pannonictis nestii (Galictinae, Mustelidae), a new element in the vertebrate association of the human site of Pirro Nord (Italy, Early Pleistocene). Geodiversitas 34, 665-681.

Cooke, H.B.S., 1985. Ictonyx bolti, a new Mustelid from cave breccias at Bolt's farm, Sterkfontein area, South Africa. South African Journal of Science 81, 618-619.

Delson, E., Hoffstetter, R., 1993. Theropithecus from Ternifine, Algeria, in: Jablonski, N.G., (Ed.), Theropithecus, the rise and fall of a primate genus. Cambridge Univ. Press, Cambridge, pp. 191-208.

Eisenmann, V., 1981. Etude des dents jugales inférieures des Equus (Mammalia, Perissodactyla) actuels et fossiles. Palæovertebrata 10, 127-226.

Ennouchi, E., 1957. Les Ursidés marocains. Bulletin de la Société des Sciences Naturelles et Physiques du Maroc, 37, 202-233.

Ewer, R.F., Singer, R., 1956. Fossil Carnivora from Hopefield. Annals of the South African Museum 42, 335-347.

Ficcarelli, G., Torre, D., 1967. Il mustelide Enhydrictis galictoides del Pleistocene della Sardegna, Palaeontographia Italica 33, 139-160.

García-Alix, A., Minwer-Barakat, R., Martín Suárez, E., Freudenthal, M., Aguirre, J., Kaya, F., 2016. Updating the Europe-Africa small mammal exchange during the late Messinian. Journal of Biogeography 43, 1336-1348.

García, N., Howell, F.C., 2008. New discovery of a large mustelid - Pannonictis cf. nestii (Carnivora: Mammalia) from the early Pleistocene locality of Sima del Elefante (Sierra de Atapuerca, Spain). Palaeontographica A 284, 1-16. 
Geraads, D., 1980. Un nouveau Félidé (Fissipeda, Mammalia) du Pléistocène moyen du Maroc: Lynx thomasi n.sp. Geobios 13, 441-444.

Geraads, D., 1981. Bovidae et Giraffidae (Artiodactyla, Mammalia) du Pléistocène de Ternifine (Algérie). Bulletin du Muséum National d'Histoire Naturelle, $4^{\text {ème }}$ sér., C, 3, 47-86.

Geraads, D., 1997. Carnivores du Pliocène terminal de Ahl al Oughlam (Casablanca, Maroc). Geobios 30, 127-164.

Geraads, D., 1998. Rongeurs du Mio-Pliocène de Lissasfa (Casablanca, Maroc). Geobios 31, 229-245.

Geraads, D., 2004. First record of Dinofelis (Felidae, Mammalia) from North Africa. Neues Jahrbuch für Geologie und Paläontologie Monatshefte 2004, 308-320.

Geraads, D., 2008. Plio-Pleistocene Carnivora of Northwestern Africa: a short review. Comptes-rendus Palevol 7, 591-599.

Geraads, D., 2010. Biogeographic relationships of Pliocene and Pleistocene North-western African Mammals. Quaternary International 212, 159-168.

Geraads, D., 2011. A revision of the fossil Canidae (Mammalia) of North-western Africa. Palaeontology 54, 429-446.

Geraads, D., Alemseged, Z., Reed, D., Wynn, J., Roman, D.C., 2004. The Pleistocene fauna (other than Primates) from Asbole, lower Awash Valley, Ethiopia, and its environmental and biochronological implications. Geobios 37, 697-718.

Geraads, D., Bernoussi, R., 2016. La faune de vertébrés du Pléistocène moyen de la Grotte des Rhinocéros, Casablanca, Maroc : 6 - Carnivora, in: Raynal, J.-P., Mohib, A. (Eds.), Préhistoire de Casablanca 1 - La Grotte des Rhinocéros (fouilles 1991 et 1996). Villes et Sites Archéologiques du Maroc 6, pp. 111-119.

Geraads, D., Bobe, R., Reed, D., Alemseged, Z., 2015. Pliocene Carnivora (Mammalia) from the Hadar Formation at Dikika, Lower Awash Valley, Ethiopia. Journal of African Earth Sciences 107, 28-35.

Geraads, D., Hublin, J.-J., Jaeger, J.-J.., Tong, H., Sen, S., Toubeau, P., 1986. The Pleistocene Hominid site of Ternifine, Algeria: new results on the environment, age and human industries. Quaternary Research 25, 380-386.

Gibert, L., Scott, G.R., Scholz, D., Budsky, A., Ferràndez, C., Ribot, F., Martin, R.A., Lería, M., 2016. Chronology for the Cueva Victoria fossil site (SE Spain): Evidence for Early Pleistocene Afro-Iberian dispersals. Journal of Human Evolution 90, 183-197. 
Haile-Selassie, Y., 2008. New observations on the Late Miocene-Early Pliocene Lutrinae (Mustelidae: Carnivora, Mammalia) from the Middle Awash, Afar Rift, Ethiopia. Comptes-rendus Palevol 7, 557-569.

Hartstone-Rose, A., Werdelin, L., De Ruiter, D.J., Berger, L.R., Churchill, S.E., 2010. The Plio-Pleistocene ancestor of wild dogs, Lycaon sekowei n.sp. Journal of Paleontology 84, 299-308.

Hemmer, H., Kahlke, R.D., Keller, T., 2003. Panthera onca gombaszoegensis (Kretzoi, 1938) aus den frühmittelpleistozänen Mosbach-Sanden (Wiesbaden, Hessen, Deutschland) Ein Beitrag zur Kenntnis der Variabilität und Verbreitungsgeschichte des Jaguars. Neues Jahrbuch für Geologie und Paläontologie Abhandlungen 229, 31-60.

Hemmer, H., Kahlke, H.-D., Vekua, A., 2010. Panthera onca georgica ssp. nov. from the Early Pleistocene of Dmanisi (Republic of Georgia) and the phylogeography of jaguars (Mammalia, Carnivora, Felidae). Neues Jahrbuch für Geologie und Paläontologie Abhandlungen 257, 115-127.

Hendey, Q.B., 1974. The late Cenozoic Carnivora of the South-Western Cape Province. Annals of the South African Museum 63, 1-369.

Hendey, Q.B., 1978. Late Tertiary Mustelidae (Mammalia, Carnivora) from Langebaanweg, South Africa. Annals of the South African Museum 76, 329-357.

Hublin, J.-J., 2001. Northwestern African Middle Pleistocene hominids and their bearing on the emergence of Homo sapiens, in: Barham, L, Robson-Brown, K, (Eds.), Human Roots. Africa and Asia in the Middle Pleistocene. Western Academic and Specialist Press, Bristol, pp. 99-121.

Jaeger, J.-J., 1988. Origine et évolution du genre Ellobius (Mammalia, Rodentia) en Afrique Nord-Occidentale. Folia Quaternaria 57, 3-50.

Kormos, T., 1931. Pannonictis pliocaenica n. g. n. sp., a new giant mustelid from the Late Pliocene of Hungary. Magyar Királyi Földtani Intézet évkönyve 29, 1-16.

López-Antoñanzas, R, Gutkin, V, Rabinovich, R, Calvo, R, Grossman, A.,2016. A transitional gundi (Rodentia: Ctenodactylidae) from the Miocene of Israel. PlosOne 11, e0151804.

Major, C.I. Forsyth, 1901. On Enhydrictis galictoides, a new fossil from Sardinia. Proceedings of the Zoological Society of London 2, 625-628.

Morlo, M., Kundrat, M., 2001. The first carnivoran fauna from the Ruscinium (Early Pliocene, MN 15) of Germany. Paläontologische Zeitschrift 75, 163-187.

O’Regan, H.J., Cohen, B.F., Steininger, C.M., 2013. Mustelid and viverrid remains from the 
Pleistocene site of Cooper's D, Gauteng, South Africa. Palaeontologia Africana 48, 19 23.

Olive, F., 2006. Évolution des grands Carnivores au Plio-pléistocène en Afrique et en Europe occidentale. L'Anthropologie, 110, 850-869.

Peigné, S., Bonis, L. de, Mackaye, H.T., Andossa, L., Vignaud, P., Brunet, M., 2008. Late Miocene Carnivora from Chad: Herpestidae, Viverridae and small-sized Felidae. Comptes-rendus Palevol 7, 499-527.

Petter, G., 1973. Carnivores pléistocènes du ravin d'Olduvai (Tanzanie). Fossil Vertebrates of Africa 3, 43-100.

Petter, G., 1987. Small carnivores (Viverridae, Mustelidae, Canidae) from Laetoli, in: Leakey, M.D., Harris, J.M., (Eds.), Laetoli, a Pliocene site in Northern Tanzania. Clarendon Press, Oxford, pp. 194-234.

Petter, G., Howell, F.C., 1985. Diversité des carnivores (Mammalia, Carnivora) dans les faunes du Pliocène moyen et supérieur d'Afrique orientale. Indications paléoécologiques, in: L'environnement des Hominidés au Plio-Pléistocène, SingerPolignac, Paris, pp. 133-150.

Petter, G., Pickford, M., Howell, F.C., 1991. La loutre piscivore du Pliocène de Nyaburogo et de Nkondo (Ouganda, Afrique Orientale): Torolutra ougandensis n.g., n.sp.

(Mammalia, Carnivora). Comptes-rendus de l'Académie des Sciences, II, 312, 949-955.

Pomel, A., 1878. Ossements d'éléphants et d'hippopotames découverts dans une station préhistorique de la plaine d'Eghis (Province d'Oran). Bulletin de la Société géologique de France 3, 44-51.

Pomel, A., 1897. Les carnassiers. Carte géologique de l'Algérie - Paléontologie Monographies, 1-42.

Prat, F., Thibault, C., 1976. Le gisement de Nauterie à la Romieu ( Gers). Fouilles de 1967 à 1973. Nauterie I. Mémoires du Muséum National d'Histoire Naturelle C 35, 1-82.

Qiu, Z., Deng, T., Wang, B., 2003. Early Pleistocene mammalian fauna from Longdan, Dongxiang, Gansu, China. Palaeontologia Sinica 191, NS C 27, 1-198.

Rabeder, G., 1976. Die Carnivoren (Mammalia) aus dem Altpleistozän von DeutschAltenburg 2. Mit Beitragen zur Systematik einiger Musteliden und Caniden. Beiträge zur Paläontologie von Österreich 1, 5-119.

Rabeder, G., 2009. Early Pleistocene bear remains from Deutsch-Altenburg (Lower Austria). Mitteilungen der Kommission für Quartärforschung der Österreichischen Akademie der Wissenschaften 17, 1-135. 
Raynal, J.-P., Magoga, L., Sbibi-Alaoui, F.-Z., Geraads, D., 1996. The earliest occupation of Atlantic Morocco: the Casablanca evidence, in: Roebroeks, W., van Kolfschoten, T., (Eds.), The Earliest Occupation of Europe. Univ. Leiden, pp. 255-262.

Rook, L., 1995. Pannonictis nestii (Carnivora Mammalia) from the Late Villafranchian of Pietrafitta (Umbria, Italy). Preliminary note. Eclogae Geologicae Helvetiae 88, 853-864.

Sato, J.J., Wolsan, M., Prevosti, F.J., D’Elia, G., Begg, C., Begg, K., Hosoda, T., Campbell, K.L., Suzuki, H., 2012. Evolutionary and biogeographic history of weasel-like carnivorans (Musteloidea). Molecular Phylogenetics and Evolution 63, 745-757.

Schaub, S., 1949. Révision de quelques carnassiers villafranchiens du niveau des Etouaires, montagne de Perrier, Puy-de Dôme. Eclogae Geologicae Helvetiae 42, 491-506.

Schreuder, A., 1935. A note on the Carnivora of the Tegelen Clay, with some remarks on the Grisoninae. Archives Néerlandaises de Zoologie 2, 73-94.

Sotnikova, M.V., 1980. [Late Pliocene Mustelidae from Shamar (Mongolia)]. Bulleten Komissii Po Izucheniu Chetvertichnogo Perioda 50, 139-145. [In Russian]

Sotnikova, M.V., Sablin, M.V., 1993. [The late Villafranchian association of carnivorous mammals from the locality Palan-Tyukan (Eastern Transcaucasia, Azerbaijan)]. Proceedings of the Zoological Institute Russian Academy of Sciences 249, 134-145. [In Russian]

Sotnikova, M.V., Baigusheva, V.S., Titov, V.V., 2002. Carnivores of the Khapry faunal assemblage and their stratigraphic implications. Stratigraphy and geological correlation $10,375-390$.

Spassov, N., 2003. The Plio-Pleistocene vertebrate fauna in South-Eastern Europe and the megafaunal migratory waves from the East to Europe. Revue de Paléobiologie, Genève 22, 197-229.

Stöck, M., Sicilia, A., Belfiore, N.M., Buckley, D., Lo Brutto, S., Lo Valvo, M., Arculeo, M., 2008. Post-Messinian evolutionary relationships across the Sicilian channel:

Mitochondrial and nuclear markers link a new green toad from Sicily to African relatives BMC Evolutionary Biology 8, 56.

Teilhard de Chardin, P., Piveteau, J., 1930. Les mammifères fossiles de Nihowan (Chine). Annales de Paléontologie 19, 1-134.

Tong, H., 1986. The Gerbillinae (Rodentia) from Tighenif (Pleistocene of Algeria) and their significance. Modern Geology 10, 197-214.

Turner, A., 1987. New fossil carnivore remains from the Sterkfontein hominid site 
(Mammalia: Carnivora). Annals of the Transvaal Museum 34, 319-347.

Viret, J., 1954. Le loess à bancs durcis de Saint-Vallier (Drôme) et sa faune de mammifères villafranchiens. Nouvelles Archives du Muséum d'Histoire naturelle de Lyon 4, 1-200.

Wagner, J., 2010. Pliocene to early Middle Pleistocene ursine bears in Europe: a taxonomic overview. Journal of the National Museum (Prague), Natural History Series 179, $197-215$.

Werdelin, L., 1981. The evolution of lynxes. Annales Zoologici Fennici 18, 37-71.

Werdelin, L., Lewis, M.E., 2001. A revision of the genus Dinofelis (Mammalia, Felidae). Zoological Journal of the Linnean Society 132, 147-258.

Werdelin, L., Dehghani, R., 2011. Chapter 8 - Carnivora, in: Harrison, T., (Ed.), Paleontology and Geology of Laetoli: Human Evolution in Context. Springer, Dordrecht, pp. 189-232.

Werdelin, L., Lewis, M., 2013. Koobi Fora Research Project. Volume 7. The Carnivora. California Academy of Sciences, San Francisco.

Willemsen, G.F., 1988. Mustela and Enhydrictis (Carnivora, Mustelidae) from Tegelen (The Netherlands). Proceedings of the Koninklijke Nederlandse Akademie van Wetenschappen Series B Physical Sciences 83, 310-326. 


\section{Table and Figure captions}

Table 1. Measurements of Crocuta crocuta upper teeth.

Table 2. Measurements of Crocuta crocuta lower teeth.

Table 3. Comparative measurements of $H$. hyaena from Tighennif, OH1-GDR, and a modern sample.

Table 4. Measurements of felid teeth.

Table 5. Measurements of Panthera metapodials.

Table 6. Measurements of North African early to middle Pleistocene Ursus teeth.

Table 7. Measurements of Mellivora teeth and skulls. Abbreviation: occip., occipital.

Table 8. Measurements of Vulpes cf. rueppelli upper teeth.

Table 9. Measurements of Lupulella mohibi upper teeth.

Table 10. Measurements of Lupulella mohibi lower teeth.

Table 11. Total number of specimens of terrestrial carnivores identified in the Pleistocene fossil locality of Tighennif (= Ternifine, Northern Algeria).

Fig. 1. A-E. Enhydrictis hoffstetteri nov. sp. A-C: holotype, right mandible with c-m1, TER2008, in buccal (A), lingual (B), and occlusal (C, stereo) views; D: unregistered right M1, occlusal stereo-view; E: unregistered left M1, occlusal stereo-view. F. Lupulella mohibi, mandible, TER-2057, occlusal stereo-view. G. Lycaon magnus, unregistered P2 and P3, buccal view. H. Ursus aff. bibersoni, left mandibular fragment, lateral view. I, J. Crocuta crocuta. I: mandible, TER-2151, lateral view; J: mandible, TER-2158, occlusal stereo-view. 
K. Hyaena hyaena, maxilla, TER-2161, occlusal view. Scale bar: $2.5 \mathrm{~cm}(\mathrm{~A}-\mathrm{E}, \mathrm{G}), 5 \mathrm{~cm}$ (F), $10 \mathrm{~cm}(\mathrm{H}-\mathrm{K})$.

Fig. 2. Principal component analysis on length and width of lower p2-m1 of Crocuta (the analysis includes only specimens on which all measurements are available).

Fig. 3. A-D. Lynx sp. A, B: right mandible with p3-m1 TER-2024 in lingual (A) and buccal (B) views; C, D: left mandible with p3-m1, TER-2023, in lingual (C) and buccal (D) views. E, F. Felis silvestris, left maxilla with P3-P4, in buccal (E) and occlusal (F) views. G-I. Homotherium sp., right p3-p4, in buccal (G), occlusal (H, stereo), and lingual (I) views. J-L. Panthera aff. leo. J: left distal humerus, TER-2298; K, L: right mandibular fragment with p2-m1, TER-2173, in buccal (K) and occlusal (L, stereo) views. Scale bar: 5 cm (A-D, G-I, $\mathrm{K}, \mathrm{L}), 2.5 \mathrm{~cm}(\mathrm{E}, \mathrm{F}), 10 \mathrm{~cm}(\mathrm{~J})$. 


\section{Table 1.}

\begin{tabular}{lllllll}
\hline & L P2 & W P2 & L P3 & W P3 & L P4 & W P4 \\
\hline TER-2159 & 17.1 & 13.1 & 23.6 & 16.7 & 40.3 & 22.3 \\
TER-2213 & - & - & 20.2 & 17.1 & 39.1 & 21.1 \\
TER-2197 & - & - & 22 & 15.5 & - & - \\
\hline
\end{tabular}


Table 2.

\begin{tabular}{|c|c|c|c|c|c|c|c|c|c|}
\hline & L p2 & W p2 & L p3 & W p3 & L p4 & W p4 & $\mathrm{L} \mathrm{m} 1$ & $\mathrm{~W}$ m1 & L tri \\
\hline TER-2150 & 16.7 & 11.5 & 21.4 & 16.1 & 23.3 & 14.6 & 29.0 & 12.3 & 26.1 \\
\hline TER-2151 & 13.8 & 7.7 & 20.0 & 13.9 & 21.7 & 12.4 & 29.3 & 11.8 & 26.8 \\
\hline TER-2152 & 15.2 & 10.8 & 19.9 & 14.8 & 21.8 & 13.3 & 27.7 & 12.0 & 24.7 \\
\hline TER-2153 & 14.9 & 11.0 & 20.7 & 15.5 & - & - & - & - & - \\
\hline TER-2154 & - & - & 21.1 & 15.2 & - & 14.3 & - & & _ \\
\hline TER-2155 & 15.2 & 11.2 & 22.3 & 16.1 & - & - & - & - & - \\
\hline TER-2156 & 14.5 & 11.0 & 21.3 & 15.6 & 22.0 & 13.5 & 29.9 & 12.0 & 26.6 \\
\hline TER-2158 & 16.0 & 10.8 & 20.1 & 14.3 & 22.7 & 13.0 & 28.3 & 12.5 & 26.0 \\
\hline TER-2185 & $\begin{array}{lll}- & - \\
-1\end{array}$ & - & - & - & - & - & 28.6 & 12.3 & 24.5 \\
\hline TER-2186 & - & - & - & - & - & - & 30.3 & 13.1 & 26.8 \\
\hline TER-2188 & - & - & - & - & - & te & 29.4 & 12.7 & 25.4 \\
\hline TER-2193 & - & - & - & - & 20.8 & 13.9 & - & - & - \\
\hline TER-2200 & - & - & - & - & 22.0 & 13.4 & - & - & - \\
\hline TER-2202 & - & - & - & - & - & 13.7 & - & - & - \\
\hline TER-2212 & 14.3 & 10.1 & - & - & - & - & - & - & - \\
\hline TER-2214 & - & - & 21.3 & 14.3 & 23.2 & 13.0 & - & - & - \\
\hline TER-2216 & - & - & 21.5 & 16.2 & - & - & - & - & - \\
\hline TER-2217 & - & - & 19.8 & 14.3 & _- & - & - & - & - \\
\hline TER-2218 & 15.2 & 10.4 & - & - & - & - & - & - & - \\
\hline TER-2219 & 15.7 & - & - & - & - & - & - & - & - \\
\hline mean Tighennif & 15.1 & 10.5 & 20.9 & 15.1 & 22.2 & 13.5 & 29.1 & 12.3 & 25.9 \\
\hline Modern $(\mathbf{N}=32)$ & 15.4 & 10.6 & 20.8 & 14.9 & 22.7 & 13.1 & 28.9 & 11.8 & - \\
\hline
\end{tabular}


Table 3.

\begin{tabular}{llllllll}
\hline & L P2 & W P2 & L P3 & W P3 & L P4 & W P4 & W M1 \\
\hline TER-2161 H. hyaena & 15.7 & 10.5 & 21.0 & 14.1 & 32.0 & 18.0 & 15.8 \\
TER-2164 H. hyaena & - & - & 20.6 & 12.1 & - & - & - \\
GDR F14-67 H. hyaena & c. 14 & 10.0 & 20.3 & 13.0 & 31.4 & 18.3 & 14.6 \\
Recent, mean (N = 17) & 15.6 & 10.0 & 20.2 & 13.7 & 30.1 & 18.8 & 13.8 \\
\hline
\end{tabular}


Table 4.

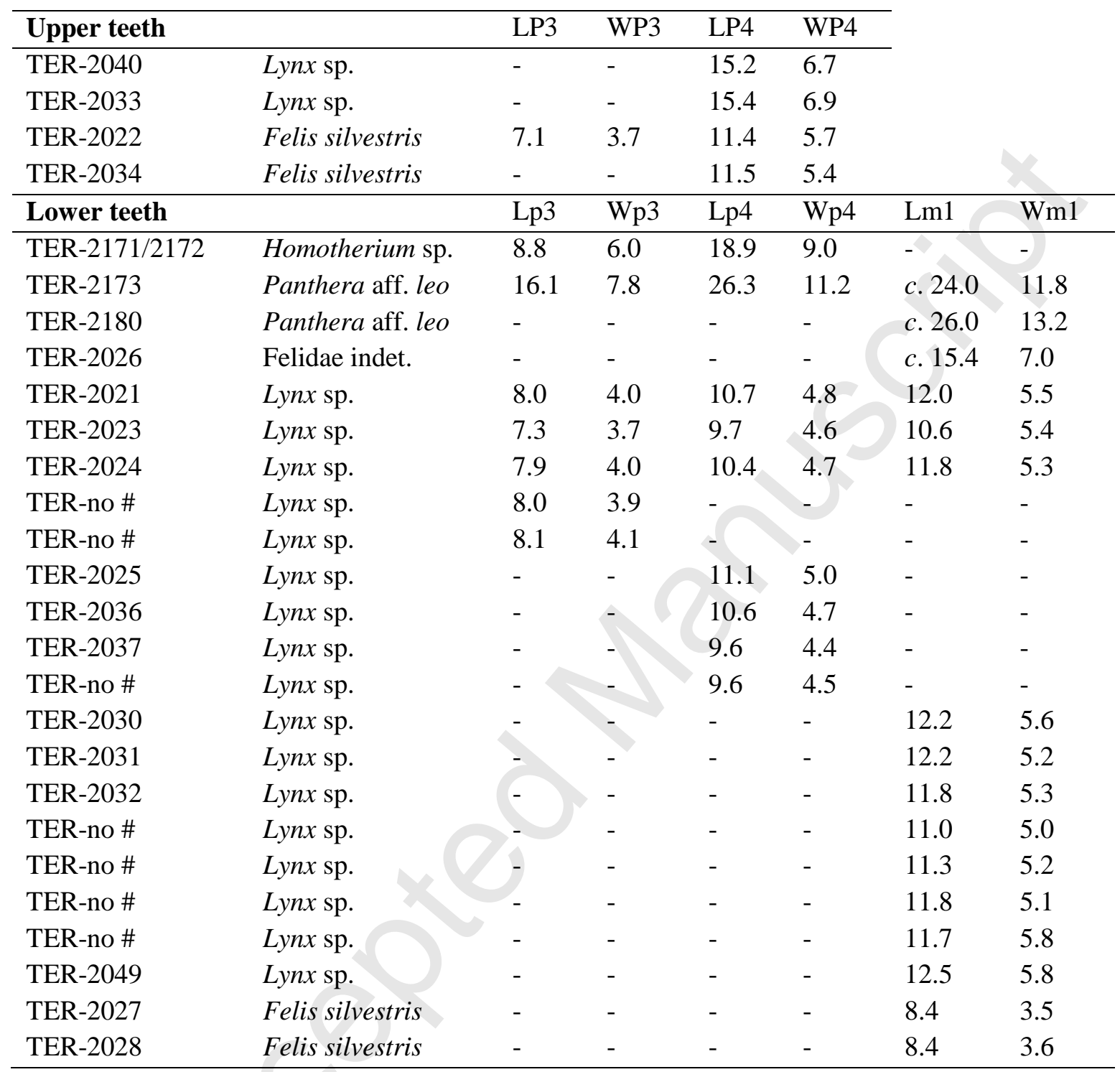


Table 5.

\begin{tabular}{lllll}
\hline & Max. length & Max. proximal W & W of shaft & Max. distal W \\
\hline Mc II TER-2258 & 95.7 & 23.5 & 15.1 & 22.3 \\
Mc III TER-2254 & c. 106 & 28.1 & 16.4 & 24.6 \\
Mc III TER-2257 & 109.3 & - & 17.0 & 25.1 \\
Mc V TER-2256 & c. 82 & 19.0 & 14.7 & 21.0 \\
Mt IV TER-2252 & $>134$ & 29.0 & 17.2 & 22.8 \\
Mt IV TER-2253 & c. 130 & 25.2 & 15.5 & - \\
\hline
\end{tabular}


Table 6.

\begin{tabular}{|c|c|c|c|c|c|}
\hline & $\mathrm{P} 4$ & $\mathrm{~W} \mathrm{~m} 1$ & $\mathrm{~L} \mathrm{~m} 2$ & $\mathrm{~W} \mathrm{~m} 2$ & $\mathrm{~L} \mathrm{~m} 3$ \\
\hline TER-2003 & $16.4 \times 13$ & - & - & - & - \\
\hline TER-2002 & - & - & - & - & $22 ?$ \\
\hline TER-2001 & - & 13 & $28 ?$ & c. 18.5 & $22.5 ?$ \\
\hline GDR-G10-47 & - & - & - & - & 27.5 \\
\hline GDR-D13-50 & $19.4 \times 15$ & - & - & - & - \\
\hline GDR-7674 & $18.8 \times 13.2$ & - & - & - & - \\
\hline GDR-E14-29 & - & 11 & 25.8 & 16.4 & $23.5 ?$ \\
\hline Thomas quarries a & $18 \times 13.5$ & $11.5-12$ & - & $16.5-18.4$ & \\
\hline Grotte des Ours ${ }^{b}$ & - & 14 & 32 & 19 & 28 \\
\hline Grotte des Ours ${ }^{\text {a }}$ & $20 \times 14$ & 14 & $31-33$ & $18-19$ & 28,29 \\
\hline
\end{tabular}

a isolated teeth; ${ }^{b}$ complete mandible (Ennouchi, 1957). 
Table 7.

\begin{tabular}{|c|c|c|c|c|c|c|c|c|c|c|c|}
\hline & Lp3 & $\mathrm{Wp} 3$ & Lp4 & Wp4 & Lm1 & $\mathrm{Wm} 1$ & bi-condylar W & bi-mastoid W & H occip. & $\begin{array}{l}\text { mini. post- } \\
\text { orbital W }\end{array}$ & $\begin{array}{l}\mathrm{L} \text { glenoid fossa to } \\
\text { parocc. }\end{array}$ \\
\hline \multicolumn{12}{|l|}{ M. capensis } \\
\hline TER-2013/16 & 7.8 & 5.8 & 11.8 & 6.6 & 14.5 & 6.6 & 38.0 & 89.0 & 45.0 & 36.3 & 52.5 \\
\hline TER-no\# & - & - & 9.9 & 6.3 & - & - & - & - & - & - & - \\
\hline modern max. & 8.0 & 6.0 & 11.7 & 7.6 & 16.3 & 8.0 & 37.1 & 96.4 & 48.5 & 36.0 & 47.6 \\
\hline modern mean & 6.7 & 5.2 & 9.6 & 6.1 & 13.8 & 6.5 & 33.0 & 75.2 & 42.2 & 31.9 & 41.4 \\
\hline modern mini. & 5.8 & 4.2 & 8.5 & 5.1 & 12.2 & 5.6 & 28.0 & 62.2 & 36.0 & 26.1 & 34.5 \\
\hline Elandsf. min. & 6.3 & 4.4 & 9.4 & 5.4 & 13.2 & 6.2 & - & 59.5 & 37.0 & 26.2 & - \\
\hline Elandsf. max. & 6.8 & 5.4 & 9.5 & 6.8 & 15.4 & 7.1 & - & 84.5 & 41.0 & 29.0 & - \\
\hline Thomas I & - & - & - & - & - & - & 32.5 & 85.5 & 40.0 & 40.0 & 42.0 \\
\hline Asbole & 6.8 & 4.9 & 9.9 & 6.0 & 15.4 & 7.6 & 36.5 & 80.0 & 47.5 & 34.5 & 46.2 \\
\hline \multicolumn{12}{|l|}{ M. benfieldi? } \\
\hline $\mathrm{AaO}-1348$ & - & - & - & - & 13.2 & 6.0 & - & - & - & - & - \\
\hline $\mathrm{AaO}-3497$ & 7.2 & 4.5 & 9.5 & 5.5 & 12.1 & 5.8 & - & - & - & - & - \\
\hline $\mathrm{AaO}-3065$ & 6.1 & 4.7 & 9.7 & 5.4 & - & - & - & - & - & - & - \\
\hline LGB-L50443 & - & - & 8.4 & 5.2 & 12.6 & 6 & - & - & - & - & - \\
\hline LGB-L31273 & - & - & - & - & 13.5 & 6.1 & - & - & - & - & - \\
\hline LGB-L42838 & 6.2 & 4.4 & 8.4 & 4.8 & 11.5 & 5.3 & - & - & - & - & - \\
\hline LGB-L6385 & - & - & 9.4 & 5.3 & 14.1 & 6.0 & - & - & - & - & - \\
\hline
\end{tabular}


Table 8.

\begin{tabular}{lllllllll}
\hline & L P3 & W P3 & L P4 & W P4 & L M1 & W M1 & L M2 & W M2 \\
\hline TER-2055* & 7.1 & 2.7 & 10.8 & 5.6 & 8.8 & 10.4 & 5.7 & 8.0 \\
TER- no \# A & - & - & 9.6 & 4.7 & - & - & - & - \\
TER-2077 & - & - & 10.4 & 5.8 & - & - & - & - \\
TER-2078 & - & - & 9.7 & 5.0 & - & - & - & - \\
TER- no \# B & - & - & 10.3 & 5.2 & - & - & - & - \\
TER- no \# C & - & - & - & - & 7.6 & 8.7 & - & - \\
TER- no \# D & - & - & - & - & 7.7 & 8.5 & - & - \\
TER- no \# E & - & - & - & - & - & - & 5.2 & 7.6 \\
\hline
\end{tabular}


Table 9.

\begin{tabular}{llllllllll}
\hline & L P4 & $\mathrm{L}_{\max }$ P4 & W P4 & & L M1 & W M1 & & L M2 & W M2 \\
\hline TER-2102 & 14.6 & 16.1 & 9.0 & TER-2059 & 10.5 & 12.6 & TER-2135 & 7.9 & 10.5 \\
TER-2103 & 15.1 & 16.3 & 7.7 & TER-2060 & 11.7 & 13.1 & TER-2136 & 8.2 & 11.5 \\
TER-2104 & 14.6 & 16.2 & 7.4 & TER-2061 & 11.6 & 13.5 & TER-2138 & 7.7 & 10.1 \\
TER-2105 & 15.1 & 15.7 & 7.8 & TER-2062 & 10.5 & 13.5 & TER-2139 & 7.3 & 9.7 \\
TER-2106 & 15.3 & 16.0 & 7.7 & TER-2063 & 11.7 & 13.3 & TER-2140 & 7.2 & 10.0 \\
TER-2107 & 13.5 & 13.5 & 7.6 & TER-2064 & 11.5 & 13.0 & TER-2141 & 7.9 & 10.6 \\
TER-2108 & 13.4 & 13.7 & 6.5 & TER-2065 & 11.4 & 13.6 & TER-2142 & 7.4 & 9.5 \\
TER-2109 & 14.1 & 14.7 & 7.2 & TER-2066 & 12.2 & 14.5 & & & \\
TER-2110 & 14.1 & 15.3 & 8.0 & TER-2067 & 12.0 & 14.2 & & & \\
TER-2129 & 13.5 & 14.6 & 8.0 & TER-2068 & 12.2 & 14.1 & & & \\
& & & & TER-2069 & 12.4 & 14.2 & & & \\
\hline Mean Tighennif & 14.3 & 15.2 & 7.7 & & 11.6 & 13.6 & & 7.7 & 10.2 \\
Mean Th-OH & 13.7 & 14.6 & 7.3 & & 11.3 & 13.1 & & 7.5 & 10.1 \\
\hline
\end{tabular}


Table 10.

\begin{tabular}{|c|c|c|c|c|c|c|c|c|}
\hline & L p3 & W p3 & L p4 & W p4 & $\mathrm{L} \mathrm{m} 1$ & $\mathrm{~W}$ m1 & $\mathrm{L} \mathrm{m} 2$ & $\mathrm{~W}$ m2 \\
\hline TER-2057 & - & - & 9.9 & 4.2 & 18.7 & 7.7 & 10.2 & 6.7 \\
\hline TER-2058 & 8.9 & 3.7 & 10.2 & 4.6 & 18.5 & 7.5 & - & - \\
\hline TER-2052 & - & - & 9.9 & 4.7 & - & - & - & - \\
\hline TER-2074 & - & - & - & - & 16.2 & 6.4 & - & - \\
\hline TER-2075 & - & - & - & - & 17.1 & 7.5 & - & \\
\hline TER-2076 & - & - & - & - & 16.5 & 7.3 & - & - \\
\hline TER-2080 & - & - & - & - & 18.6 & 8.0 & - & \\
\hline TER-2081 & - & - & - & - & 16.0 & 7.3 & - & - \\
\hline TER-2082 & - & - & - & - & 17.2 & 7.7 & - & - \\
\hline TER-2083 & - & - & - & - & 19.3 & 8.5 & - & - \\
\hline TER-2084 & - & - & - & - & 18.2 & 8.2 & - & - \\
\hline TER-2085 & - & - & - & - & 18.8 & 8.1 & - & - \\
\hline TER-2086 & - & - & - & - & 18.7 & 8.3 & - & - \\
\hline TER-2087 & - & - & - & - & 17.5 & 7.8 & - & - \\
\hline TER-2088 & - & - & - & - & 17.4 & 7.7 & - & - \\
\hline TER-2089 & - & - & - & - & 18.9 & 8.0 & - & - \\
\hline TER-2090 & - & - & - & - & 18.8 & 8.7 & - & - \\
\hline TER-2072 & - & - & - & - & - & - & 9.9 & 7.1 \\
\hline TER-2073 & - & - & - & - & - & - & 10.4 & 6.7 \\
\hline TER-2093 & - & - & - & - & - & - & 9.5 & 6.5 \\
\hline TER-2095 & - & - & & - & - & - & 10.0 & 7.4 \\
\hline TER-2096 & - & - & - & - & - & - & 9.9 & 6.8 \\
\hline TER-2097 & - & - & - & - & - & - & 10.5 & 7.3 \\
\hline TER-2098 & - & & - & - & - & - & 9.4 & 6.0 \\
\hline TER-2099 & - & - & 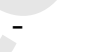 & - & - & - & 9.6 & 7.1 \\
\hline TER-2100 & - & 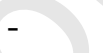 & - & - & - & - & 9.3 & 5.7 \\
\hline TER-2101 & - & 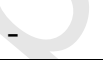 & - & - & - & - & 9.5 & 6.8 \\
\hline mean Tighennif & - & & 10.0 & 4.5 & 17.9 & 7.8 & 9.8 & 6.7 \\
\hline mean Th-OH & - & - & 8.8 & 4.3 & 16.6 & 7.1 & 9.3 & 6.6 \\
\hline
\end{tabular}


Table 11.

\begin{tabular}{ll}
\hline Crocuta crocuta & 38 \\
Hyaena hyaena & 9 \\
Felis silvestris & 9 \\
Lynx sp. & 33 \\
Felidae gen. et sp. indet. & 2 \\
Panthera aff. leo & 18 \\
Homotherium sp. & 6 \\
Ursus aff. bibersoni & 8 \\
Mellivora capensis & 6 \\
Poecilictis cf. libyca & 4 \\
Enhydrictis hoffstetteri nov. sp. & 4 \\
Vulpes cf. rueppelli & 11 \\
Lupulella mohibi & 66 \\
Lycaon magnus & 4 \\
\hline
\end{tabular}




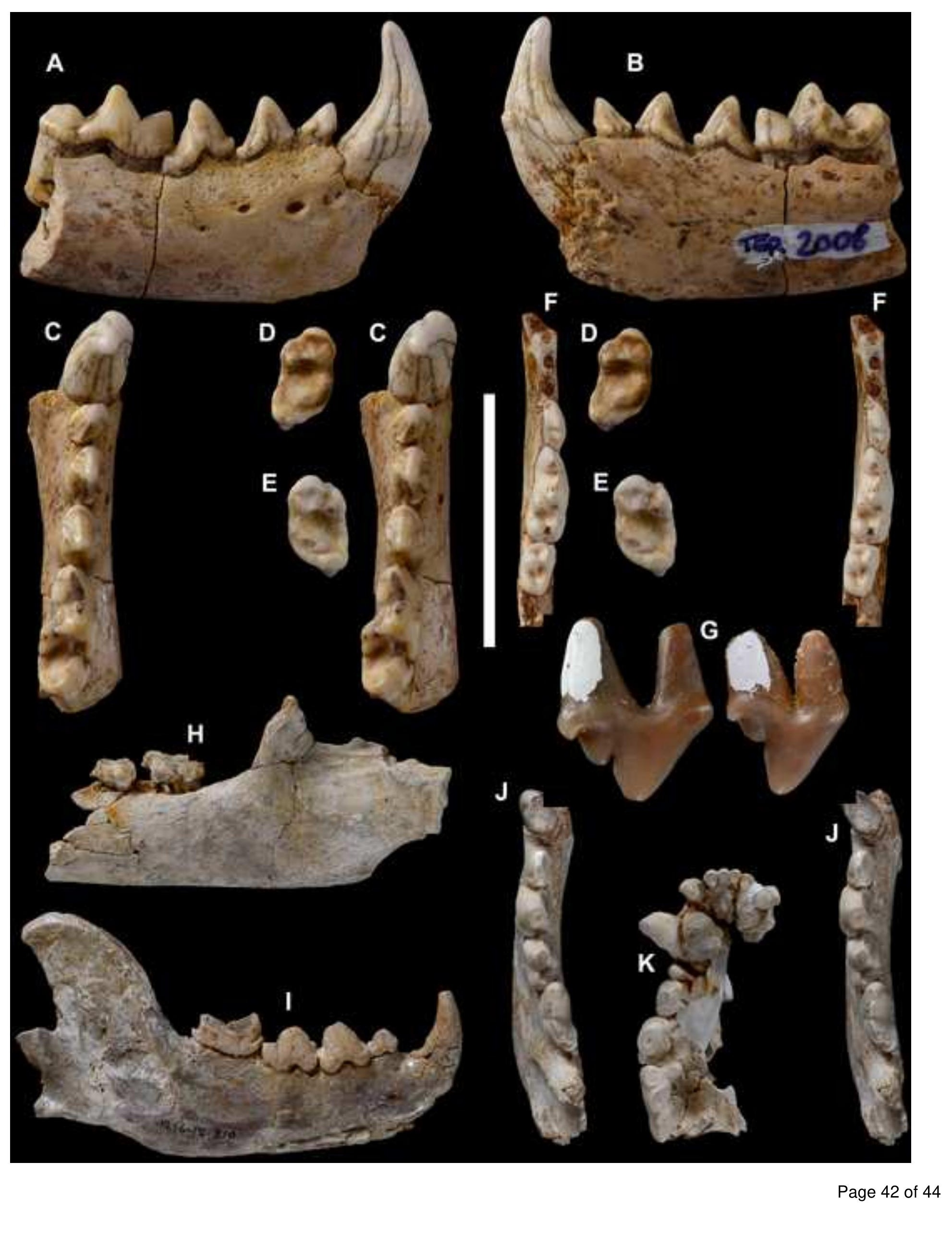

1

.

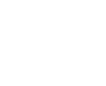

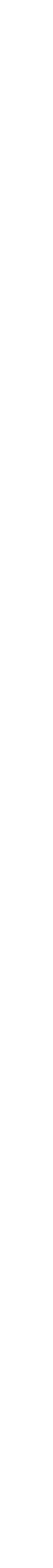




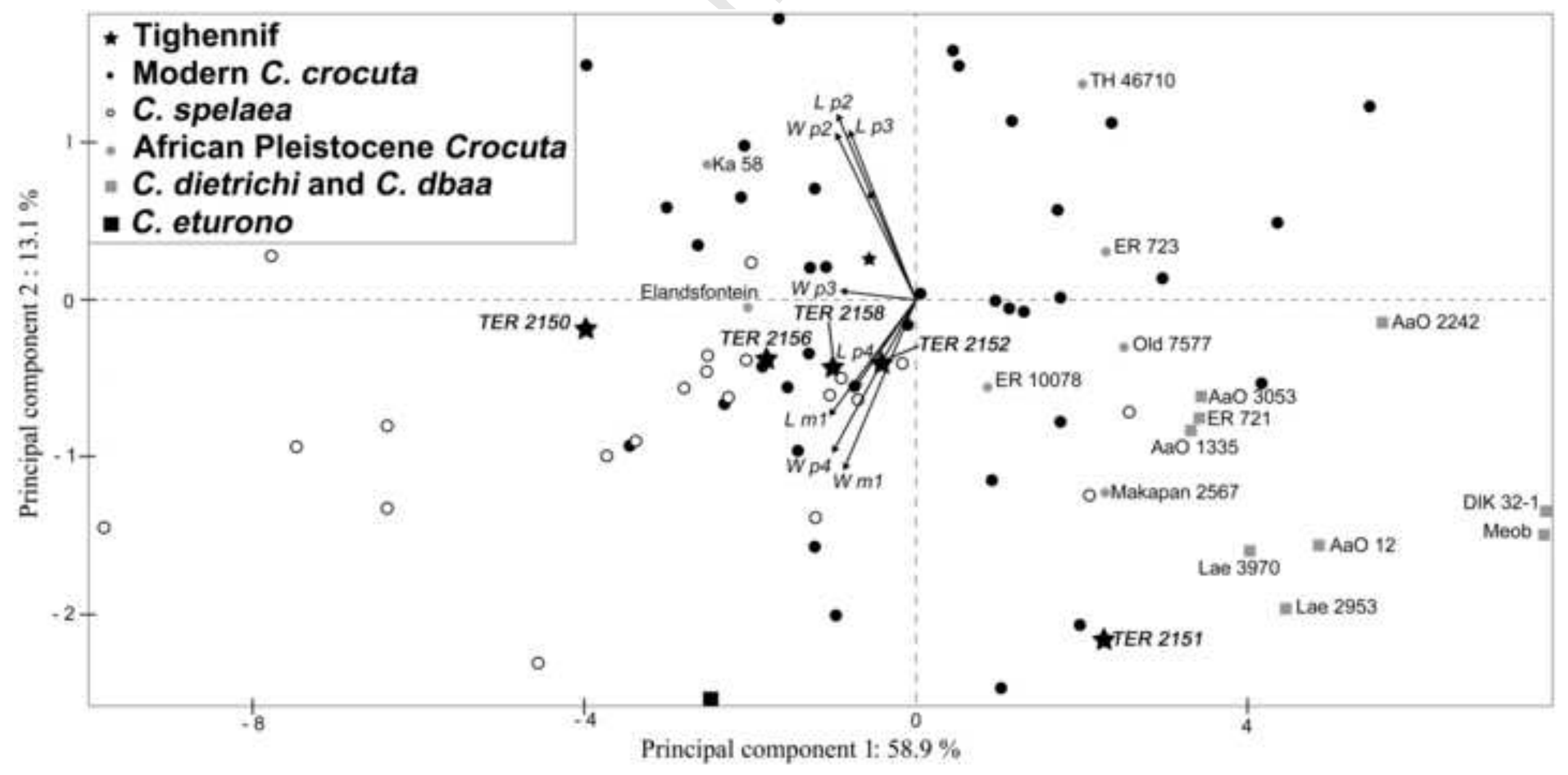




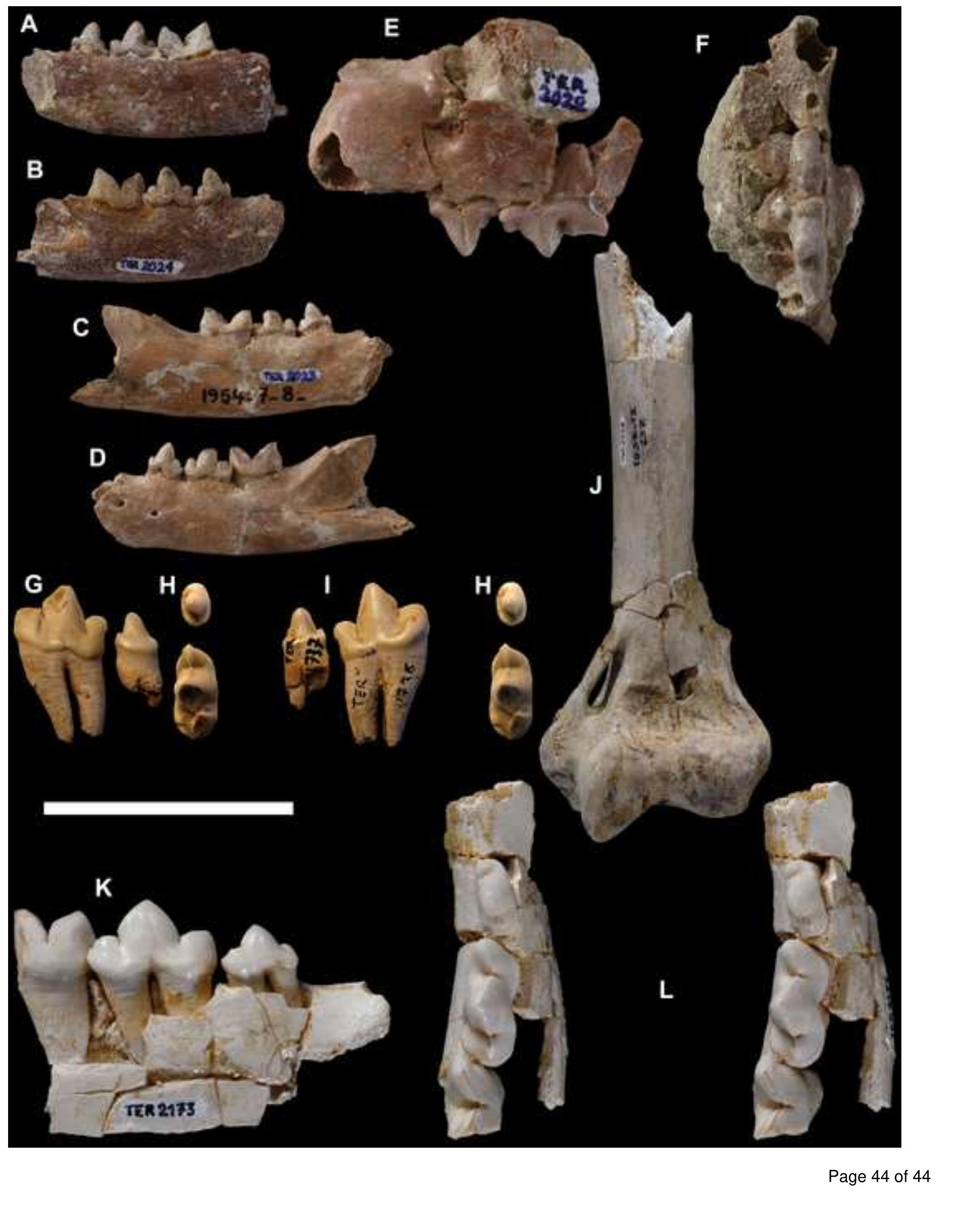

Page 44 of 44

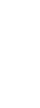<smiles>C1CC1</smiles><smiles>C=CI</smiles> 